\title{
U.S. Trade Relations with Arab Countries: Past, Present, and Future Bashar H. Malkawi*
}

Arab countries have adopted market economy principles and pursued policies designed to strengthen their economies. The cornerstone of Arab countries' long-term economic objectives has been to increase trade and support economic growth via regional and global integration. To this end, Arab countries are attempting to broaden their engagement in the multilateral trading system by joining the World Trade Organization (WTO). In addition, some Arab countries entered into trade arrangements with the United States (U.S.) to foster economic development, attract investment, and develop peaceful relationship. These trade agreements carry several implications for local economies.

The purpose of this paper is to examine the implications of the trade agreements signed between the U.S. and Arab countries on the economic and legal regimes of the latter. The paper will proceed in two main parts. The first part analyzes the preferential trade arrangement known as "Qualifying Industrial Zones" created between the U.S on the one hand and Jordan, Israel, and Egypt on the other hand. It discusses the general rules of qualifying industrial zones program and the impact of these zones on local production and employment. The second part discusses trade agreements concluded between the U.S. and Arab countries. The emphasis will be on the U.S.-Jordan Free Trade Agreement as it is considered the template for future agreements signed between the U.S. and other Arab countries. The paper analyzes the most important provisions of the U.S.-Jordan Free Trade Agreement and their implications. Then, the paper will analyze trade agreements between the U.S. and other Arab countries. The paper argues that, while current trade programs between the U.S. and those Arab countries analyzed in 
the paper required difficult reforms in their domestic laws and led some negative

consequence, on balance; these trade programs increased trade and created employment

opportunities.

\section{Qualifying Industrial Zones}

In 1994, in the aftermath of the peace treaty between Israel and Jordan, the U.S, Israel, and Jordan began to explore ways for economic cooperation. ${ }^{1}$ Earlier in this process, Israel offered to conclude an FTA but Jordan declined. ${ }^{2}$ Other initiatives involved Middle East and North Africa economic summits (Casablanca 1994, Amman 1995, Cairo 1996, and Doha 1997). These economic summits faded with the last being the Doha summit of 1997. Other projects included the establishment of a Middle East Development Bank that would facilitate private and public investment in the Middle East and North Africa. The Bank never progressed beyond studies on its creation. ${ }^{3}$ Other successful efforts culminated by the establishment of qualifying industrial zones (QIZs), an acronym pronounced like quiz in English, along the Israeli-Jordanian borders. QIZs do not require U.S congressional approval. They could be established by a presidential proclamation. ${ }^{4}$ This would give the critics little leverage to quiz them and stop the pact or force changes.

* Bashar H. Malkawi, is Assistant Professor of Law at the Hashemite University in Jordan. The author holds LL.B. from Yarmouk University 1999; LL.M. in International Trade Law from James E. Rogers College of Law, University of Arizona 2001; and S.J.D from Washington College of Law, American University 2005. Writing of this paper would not be possible without the generous support of the Brookings Institution, Saban Center for Middle East Policy. The author wishes to extend his gratitude to Tamara C. Wittes, Senior Fellow and Director of the Middle East Democracy and Development Project at the Brookings Institution, for her assistance and constructive comments that helped shape this paper.

${ }^{1}$ To secure economic dividends, the peace treaty, in article 7, states that Israel and Jordan would enter into negotiations on various economic agreements including a free trade area between them. See Treaty of Peace Between the State of Israel and the Hashemite Kingdom of Jordan, Oct. 26, 1994, 34 I.L.M. 43, 49 (1995).

${ }_{2}$ There are two reasons for Jordan's refusal to sign a bilateral trade agreement with Israel. First, Israel is an economic giant compared with its neighbor. It trades increasingly in high tech and agricultural products such as flowers, strawberries, and other exotic food. There could be no or little demand for these products in Jordan. As such, they are not naturally trading partners. Second, there was a concern that Israeli industries could crowd out Jordan's industries. Israel is the home to Teva pharmaceutical, the largest maker of generic medicine in the world. Moreover, Israel is the home of Hazera Quality Seeds, a large Israeli company specializing in genetically modifying technology which account for a large share in the U.S market along with Novartis and Monsanto.

${ }^{3}$ See Prospects Seen as Uncertain for Middle East Development Bank, 11 Int'l Trade Rep. (BNA) 43 d49 (Nov. 2, 1994) (the future of the bank is imperiled because it requires a substantial capital investment from the United Stated. Time is needed to determine its structure, financing, and how it will relate to other existing institutions such as the World Bank).

${ }^{4}$ According to the new section 9 (c) of the US-Israel Free Trade Area Implementation Act, the U.S president may proclaim that articles of Israel may be treated as though they were articles directly shipped from Israel for the purposes of the US-Israel FTA even if they were shipped to the U.S from the West 
QIZs offer opportunities for greater Israeli and Jordanian understanding through personal and professional contacts necessitated by the day-to-day operation of these QIZs. The goal of the QIZs is to provide desperately needed jobs to Jordanians taking advantage of unlimited pool of cheap labor and tax benefits. ${ }^{5}$ Also, QIZs cement the peace treaty between Israel and Jordan that otherwise may not hold water. Thus, QIZs are beneficial for all parties involved.

As of 2008, there are ten QIZs: three owned by the public sector and seven owned by the private sector. These QIZs include 97 companies employing about more than 45,000 workers. ${ }^{6}$ Total foreign investment in these QIZs stood at Jordanian Dinar 731 million in 2008. ${ }^{7}$ Over the span of ten years, exports of QIZs increased from US \$9 million in 1998 to more than US \$1.2 billion.

\section{General Rules}

Any product manufactured in QIZs can enter the U.S duty-free. In order for a product to qualify for duty free access, the product must be wholly the growth, product, or manufacture of QIZs. If not, it must be a new or different article of commerce processed in QIZ and has a value added of no less than $35 \%$ of the total value of the product. $^{8}$ The Jordanian government requested lowering the Israeli input threshold from $11.7 \%$ to $8 \%$ for the first five years of the operation of QIZs agreement between them. ${ }^{9}$ The rationale being Israeli inputs are expensive so that they would affect the final price of the product and the desire of allowing Jordan to contribute more of value added toward the final product. In fulfilling its $8 \%$ share of value added, Israeli inputs generally fall

Bank, the Gaza Strip, or a qualifying industrial zone, if the articles otherwise meet the requirements of the agreement. In other words, the article will enter the U.S duty free after meeting certain conditions. Also, the U.S president can delegate to the United States Trade Representative ("USTR") the authority to specify through notice in the Federal Register areas constituting QIZs. See Proclamation No. 6955, 61 Fed. Reg. 58761 (Nov. 13, 1996). The first QIZ is Irbid Industrial Park that was designated as such by then USTR Charlene Barshefsky in 1998.

${ }^{5}$ See Guillermo Marrero, What Foreigners Should Know About the Mexican Market, in NAFTA: What You Need To Know Now, 699 PLI/COMM. 117, 134 (1994) (there is a general trend toward "global production sharing" whereby an industrialized nation produces raw materials for assembly in developing nation with lower labor costs).

${ }^{6}$ Companies in Qualifying Industrial Zones, Jordan's Ministry of Labor, page 8, available at $<$ http://www.mol.gov.jo/qiz/qiz6-2008.pdf $>$ (June 30, 2008).

${ }^{7}$ Qualifying Industrial Zones, Jordan Investment Board, available at $<$ http:/www.jordaninvestment.com/arabic/pages.php?menu id=95\&local type=0\&local id=0\&local details $=0 \&$ local details1 $=0 \&$ localsite branchname $=\mathrm{JIB}>$ (last visited Sep. 13, 2008). See also Meeting of the Jordanian-American Committee Starts Today, Al-Rai Newspaper (Arabic) (Sep. 17, 2006).

${ }^{8}$ See Proclamation No. 6955, 61, supra note 4, ann. accompanying the proclamation. The $35 \%$ minimum content requirement is divided between Israel and Jordan according to the following:

(1) At least one-third (11.7\%) must be added by Jordan in the QIZ, and 8\% (or 7\% for high-tech products) by Israel. The remainder (15.3\%) may be accumulated by production in the QIZ, the West Bank, Gaza Strip, Israel, or the U.S or

(2) each Jordan and Israel must maintain a 20\% minimum of total production cost. See Agreement on Irbid Qualifying Industrial Zone, art. II.c, as amended, Nov. 16, 1997 (on file with author).

${ }^{9}$ The supposedly temporary 5 years period, starting in 1999 , of lowering Israeli $11.7 \%$ share to $8 \%$ has been extended several times. So now, this arrangement is a de facto permanent arrangement. 
into two categories: fabric cut in Israel or accessories such as sewing threads, zippers, plastic bags, and carton boxes. In 2007, the Jordanian government adopted new procedures for calculating production inputs designed to facilitate exportation of QIZs products. According to these new procedures, the Ministry of Industry and Trade in Jordan will calculate production inputs for QIZs products every three months instead of calculating inputs for every shipment destined for exportation.

The mechanics of QIZs work as follow: component parts are imported into the foreign owned plants in Jordan. In these plants, parts are assembled and usually the final throughput is ground-shipped back to Israel and then exported to the U.S. duty-free. For example, a woven fabric is cut into components in Israel for a shirt. Those components are assembled into a completed shirt by sewing in Jordan. A QIZs product does not carry the label "Made in Israel", "Made in Jordan", or "Made in QIZs". Merely marking a product to indicate that it is a product of a QIZ would not satisfy the U.S country of origin marking statute. ${ }^{10}$ Therefore, a QIZs product carries "Made in Jordan/QIZs" label. A QIZs product can be exported to the U.S through Israel or Jordan. However, QIZs products are usually exported through Haifa port, the largest port in Israel.

QIZs products could not be sold in the domestic Israeli or Jordanian market. QIZs products destined for exportation only. Therefore, QIZs products do not compete with domestic industries in Jordan. The reason for the prohibition against selling in the domestic Jordanian market is that QIZs products enjoy preferential treatment in the form of duty-free inputs and tax benefits. If QIZs products were to be sold in the domestic market in Jordan, domestic industries that produce like products to those of QIZs would at disadvantage. If QIZs products were to be sold in the domestic market in Jordan they would have to pay tariffs and other taxes to insure level playing field.

\section{Workforce in QIZs}

Young women form the overwhelming majority of workers in QIZs factories. ${ }^{11}$ The common perception that women are passive and unlikely to bring court cases or unionize explain why QIZs considers women to be desirable workers. While women are hired to be the bulk of the workforce in QIZs factories, office and management positions are almost exclusively staffed by foreign or local men. The majority of workers in QIZs come from China, India, Bangladesh, and Sri Lanka. ${ }^{12}$ These foreign workers total 33,357 workers which constitute about $67 \%$ of the workforce in QIZs. ${ }^{13}$ The total number of Jordanian workers in QIZs amount to 11,770 worker i.e. $33 \%$ of the total labor force in

\footnotetext{
${ }^{10}$ See Determination of Origin of Goods Processed in a Qualifying Industrial Zone or in Israel and the West Bank or Gaza Strip, 63 Fed. Reg. 34960-02, 34961 (June 26, 1998) (in determining the country of origin of textile and apparel products processed in a designated QIZ, Customs will exclusively apply the "wholly obtained or produced" in single country rule and if not applicable it would then apply the tariff shift rule).

${ }^{11}$ Study: 33\% Decline of Jordanian Labor Force in Qualifying Industrial Zones, Al-Rai Newspaper (Arabic) p. 45 (Feb. 19, 2008).

${ }^{12}$ See Companies in Qualifying Industrial Zones, Jordan's Ministry of Labor, supra note 6, at page 9.

${ }^{13} I d$. at page 8 .
} 
QIZs. As evidenced from the data on foreign workers, Jordanians do not fully capture the employment opportunities offered by QIZs factories. Many reasons explain nonattractiveness of QIZs for Jordanians. These reasons include lack of job security, low wages, and the distance between place of work and residential homes. The Jordanian government should institute policies to encourage Jordanians to join QIZs and ultimately replacing foreign workers. These policies include training Jordanian workers and increase minimum wages of workers.

Jobs at QIZs are not high-paying manufacturing jobs. The average wage for a worker in QIZs is \$105 a month. Some would argue that this wage would help put food on the table for those QIZs workers that otherwise may not a job at all. However, one has to wonder if garment factories have adjusted their wages so as to reflect inflation or in proportion to increase productivity. If there is no wage raise, real wages could be sagging. Wages ought to be living wages not minimum wages. Factory owners have to share some of their windfall profits caused by surging exports. This would help avoid high turnover and workers' low expectation of what they believe as unrewarding jobs.

The QIZs agreement between Israel and Jordan makes no reference to labor laws and regulations. ${ }^{14}$ Although the problem of child labor does not exist in QIZs, they created other types of labor concerns. There had been instances of occupational safety and health concerns, overtime work, and compensation in QIZs factories. ${ }^{15}$ The Jordanian government should effectively enforce its labor laws to prevent companies from abusing workers. The Jordanian government moved against a number of offenders, including shutting down three textile factories. ${ }^{16}$ The labor inspection regime in Jordan has failed. Jordan should increase the number of government inspectors (currently stands at 88). The Jordanian government ought to devote additional resources to labor enforcement by establishing telephone hot lines in the languages of foreign workers to facilitate the reporting of labor law violations; and engaging through the Jordanian foreign ministry with foreign governments to address the overseas recruitment abuses. Moreover, the Jordanian government should regulate the entry of foreign workers and employment in QIZs factories.

\section{QIZs are Garment Factories}

The main export items of QIZs are textiles and apparels as the table below illustrates. Determining what products to manufacture in QIZs is governed by three factors: manual

\footnotetext{
${ }^{14}$ See Agreement on Irbid Qualifying Industrial Zone, supra note 8.

${ }^{15}$ See Gary G. Yerkey, USTR Investigates Reports of Worker Abuse in Jordan in Violation of Free Trade Accord, 23 Int'l Trade Rep. (BNA) 774 (May 18, 2006) (A workers' advocacy group known as the National Labor Committee, based in New York, released a report the week of May 1 claiming that some apparel manufacturers in Jordan and contractors that supply foreign workers to them, notably from Bangladesh, have been engaging in human trafficking. The report said that workers have also complained of horrible working conditions in some Jordanian factories, including 20-hour days, no pay for months, and jailing for reporting supervisor abuse).

${ }^{16}$ Gary G. Yerkey, Jordan Vows to Curb Abuse of Workers, As Required under Free Trade Pact with U.S., 23 Int'l Trade Rep. (BNA) 962 (June 22, 2006).
} 
labor, tariffs, and quotas. If a would-be exported product is labor-intensive and subject to quotas and higher tariffs in the importing country then manufacturing such product in QIZs is more feasible economically. This would apply to textile and apparels since they would be subject to quotas and higher tariffs if they were to be produced outside QIZs. Manufacturing other products in QIZs that were already subject to no or lower tariffs and quotas even before the creation of QIZs does not make business sense.

Factories in QIZs can be described as "processing or assembly" plants. The textiles and apparel industry a traditional labor-intensive industry- manufacturing processes are sewing and tailoring- with limited capital and technology-technology is a sewing machine. Assembly plants do not lead to transfer of technology. Assembly alone does not contribute to the industrialization of a country like Jordan. Therefore, sub-QIZs plants should be set up. These sub-QIZs plants do not import inputs but rather are hired by the QIZs plants to perform some intermediate assembly or manufacturing process. Moreover, the Jordanian government ought to create an environment to invest in sectors other than textiles and apparels.

Value of the Leading 6 U.S imports from Jordan in 2007 under QIZs

Source: Statistics are delivered from Trade Data Services, Jordan Ministry of Industry and Trade to the author.

\section{Expansion of QIZs to Neighboring Countries}

Other countries in the region tried to participate in the QIZs scheme with varying degrees of success. The West Bank and the Gaza Strip is beneficiary of the QIZs scheme. ${ }^{17}$ However, the development of QIZs and the share of Palestinian products in QIZs production have been stymied by the security situation in Israel. For instance, the outbreak of the Palestinian uprising in 2000 forced Israelis to scrap plans for a joint

\footnotetext{
${ }^{17}$ See Determination of Origin of Goods Processed in a Qualifying Industrial Zone or in Israel and the West Bank or Gaza Strip, supra note 10.
} 
Israeli-Palestinian industrial zone in the southern Gaza Strip. Political stability is precondition for economic cooperation. Moreover, if Palestinian inputs were to be incorporated in QIZs product, some of the work done by workers in Jordan's QIZs would be replaced by Palestinians especially considering the subordinate economic and geographic relationship between the West Bank and Gaza Strip and Israel.

In 2004, an agreement on Egypt's QIZs was signed between Egypt and the U.S. ${ }^{18}$ The agreement on Egypt QIZs follows the model of Jordan's QIZs. A question arises as to whether the establishment of QIZs in Egypt affected Jordan's QIZs, positively or negatively. To answer such a question one has to lay down some of the similarities and differences between Jordan's QIZs and Egypt's QIZs.

Jordan's QIZs date back to the second half 1990s. For Israel and Egypt, QIZs will be the first formal economic engagement since the 1978 Camp David accords. Egypt's QIZs are late comeback for an economic relationship that has been virtually idle for twenty-six years. The requirements for both Jordan's QIZs agreement and Egypt's QIZs agreement are almost the same. The Egyptian trade deal allows Egypt to export goods to the U.S duty-free if they have at least 35\% of their value added in Egypt and of that amount, $11.7 \%$ must be Israeli content. ${ }^{19}$ There were shortcomings that appeared over the years in Jordan's QIZs that Israeli and Egyptian negotiators tried to avoid in the Egyptian QIZs. Egypt's QIZs set up a mechanism for submitting accounting results "quarterly.,"20 Perhaps, the "daily" work, especially on the Israeli side, of approving receipts, documents, and counting for every shipment in order to determine that products of Jordan's QIZs meet the agreement requirements has caused bottlenecks. Therefore, a mechanism of quarterly reporting by QIZs firms could facilitate the process.

In 2008, Jordan's QIZs numbered ten. On the other hand, the trade agreement between the U.S, Israel, and Egypt called for the establishment of three QIZs in Egypt. ${ }^{21}$ As of 2008, there are some 97 company operating in Jordan's QIZs. On the other hand, as of 2008, QIZs in Egypt includes 720 companies. ${ }^{22}$ Although Jordan's QIZs are older than Egypt's QIZs, companies in Egypt's QIZs outnumber those in Jordan's QIZs. Additionally, while more than $96 \%$ of QIZs in Jordan export textiles and apparels,

\footnotetext{
${ }^{18}$ See Neil King Jr. \& Greg Hitt, Three-Way Trade Pact with U.S. Marks Egypt-Israel Breakthrough, WALL ST. J., Dec. 10, 2004, at A13 (Egyptian officials have lobbied the Bush administration for months to win approval of a trade arrangement with the U.S., mainly to offset potential job losses as the Egyptian government implements changes that could prove costly in the short term. For American textile manufacturers, the initiative further dramatizes the broader forces pressuring the industry).

${ }^{19}$ See Determination of Origin of Goods Processed in a Qualifying Industrial Zone or in Israel and the West Bank or Gaza Strip, supra note 10, art. II.d.

${ }^{20}$ Article II.f of the Protocol states that the QIZ Joint Committee shall promptly provide quarterly the U.S Customs Authority and the Egyptian Customs Authority with a list of companies entitled to duty free treatment for the next quarter only. Id. art. II.f.

${ }^{21}$ The U.S designated the Greater Cairo zone, Alexandria zone, and Suez Canal zone as QIZs. See United States-Israel Free Trade Area Implementation Act: Designation of Qualifying Industrial Zones, 69 Fed. Reg. 78094-02 (Dec. 29, 2004).

${ }^{22}$ See List of Companies Entitled to QIZ Duty-Free Treatment, Egypt Ministry of Industry and Trade, available at $<$ http://www.qizegypt.gov.eg/images/QIZ Companies List Report Qverall .pdf $>$ (last visited Sep. 14, 2008).
} 
Egypt's QIZs produce textiles as well as electrical equipments and machinery. ${ }^{23}$ Egypt is considered a leading manufacturing country and its industries are more developed than those of Jordan.

As a result of Egypt's QIZs, some trade and investment diverted from Jordan to Egypt. Seventeen factories in Jordan's QIZs moved their facilities to Egypt to service the U.S market. ${ }^{24}$ Factories in Jordan's QIZs did not move out of Jordan in large numbers. Factory owners in Jordan's QIZs invested in industry and infrastructure, hired entry-level workers and trained them to become efficient well-disciplined workers. It is illogical for these owners to waste their investments. Ten years of developing Jordan's QIZs is a long period that offers factory owners rich experience that is not be available in Egypt QIZs. In addition, whether investment remains in Jordan or not depends on the general business environment-tax regime, labor and environmental laws, banking system, and availability of facilities and infrastructure- in Jordan and Egypt rather than QIZ solely. Usually, the business environment in Jordan is more hospitable compared with what some Israeli officials claim as hostile business environment in Egypt. In sum, the establishment of Egypt's QIZs diverted some trade and investment from Jordan but overall did not lead to major exodus.

\section{Assessing QIZs Scheme}

The U.S, Israel, and Jordan wanted to achieve real peace dividends so that enemies of peace will be undercut. QIZs program is an indirect trade relationship between Israel and Jordan. The parties are shy of establishing a comprehensive trade relationship. Rather, they resort to the U.S to foster their trade relationship.

The establishment of QIZs in Jordan created investment and employment opportunities. For example, in 2008, foreign investment in QIZs totaled Jordanian Dinar 731 million. Total exports increased to more than US $\$ 1.2$ billion, constituting third of Jordan's total exports. Moreover, 11,770 Jordanian workers, out of some 45,000 workers, are employed in these QIZs. However, more work need to be done to improve the contribution of QIZs to the Jordanian economy.

In order for a product to qualify for QIZs treatment, the product must be wholly the growth, product, or manufacture of QIZs. If not, it must be a new or different article of commerce processed in QIZ and has a value added of no less than 35\% of the total value of the product. Israeli input toward meeting the $35 \%$ value stands currently at $8 \%$. The Jordanian government should enter into negotiations with Israel to lower the Israeli input

\footnotetext{
${ }^{23}$ See QIZ Company Statistics, Egypt Ministry of Industry and Trade, available at $<$ http://www.qizegypt.gov.eg/images/Statistics\%20 Q2 Aug 2008 overall.pdf $>$ (last visited Sep. 14, 2008) (80 percent of QIZs production cover textile articles while the remaining is distributed between electrical equipment, plastics, machinery, and chemicals).

${ }^{24}$ See Al-Khaza'leh Reiterates Government Support; The Apparel Sector Worry from Limitations that Affect Competition, Al-Rai Newspaper (Oct. 10, 2007) (in Arabic). See also Nisreen Kurd, Conflict of Information over Number of Companies Closed in QIZs (Sep. 30, 2008).
} 
threshold to $5 \%$ or even lower. Israeli inputs are expensive so they affect the final price of the product and thus its competitiveness.

Jordan's QIZs are limited in geographical scope. They cover certain enclave areas that are designated as QIZs only. They do not extend to other geographical areas. QIZs should not be seen as a separate creature from the local economy. Thus, the Jordanian government should study the possibility of extending QIZs to other cities and permitting QIZs to sell part of their production in the local market. In addition, the Jordanian government can mandate that portion of QIZs profits be directed domestic development and capital investment instead of repatriating these profits to investors' home countries.

QIZs concentrate mainly in producing textiles and apparels. QIZs program is basically a textiles and apparels agreement. QIZs production does not cover other manufacturing products and services. Top QIZs apparel exports to the U.S. include some basic higher-volume apparel articles such as men's shirts, women's trousers, sweaters, ladies' outfits and blouses, and sportswear. There are few high value-added apparel articles such as men's wool suits and jackets. Limiting manufacturing to textiles and apparels will not help Jordan's industrialization in the long run. Further, most production inputs in QIZs are imported. Importation of inputs increase production costs and limit competitiveness. Jordan should encourage QIZs to diversify their production into areas such as information technology and Dead Sea mineral products for example. Jordan should also encourage the creation of plants that perform value-added intermediary manufacturing process.

The Jordanian government can further attract more investment in QIZs by lowering tariffs and providing tax holidays. The government can lower fees for work permits given to workers in QIZs. Moreover, the government can lower water and electricity fees for QIZs factories. Adequate finance must be available to manufacturers in QIZs. For instance, the government can lower interest rate to loans advanced to manufacturers.

Nationals of Asian countries constitute the major proportion of QIZs workers. The Jordanian government should institute a policy of encouraging Jordanians to join the labor force in QIZs. This policy includes training of qualified and adequate workers and setting quota on the number of foreign workers. There must be an increase in minimum wage. Minimum wage should be increased to US \$212 at least. The government should grant tax benefits for those investors willing to train Jordanians so as to work in QIZs. Jordan should run public awareness campaign to eradicate the culture of "shyness" among Jordanians who look at factory jobs as unworthy. The private sector can also contribute to hiring more Jordanians in QIZs by running more vocational training courses.

QIZs lead to instances of labor law(s) violations. These violations included nonpayment of wages, overtime work, and hazardous working conditions. The Jordanian government should effectively enforce its labor laws to prevent companies from abusing workers in QIZs. The government can decide to impose fines and when necessary shut down factories. Trade and investment culture in Jordan must not come at any price. QIZs 
companies must comply with local laws including labor protection or ship out to different destination.

The creation of QIZs in Egypt complicated matters for the QIZs program in Jordan. Jordan did not have an indigenous textiles and apparel industry before the establishment of QIZs, thus it faced side effects in competing with efficient garment producers from Egypt. Several factories moved from Jordan to Egypt. Factory owners in QIZs in Jordan invested heavily and did not move out in large numbers. The relationship between Jordan and Egypt ought not to be competitive solely with regard to QIZs. Both Jordan and Egypt can explore ways to collaborate their activities such as exchange in expertise and importation and exportation of certain inputs in QIZs products. 


\section{U.S. - Bilateral Trade Agreements with Arab Countries}

This part deals with trade agreements concluded between the U.S. and Jordan and other Middle Eastern countries. These free trade agreements were driven by security and political as much or more than trade concerns, but the trade concerns are important, particularly for the U.S. partners.

For the United States, the shift from a strictly global trade liberalization policy to the acceptance of the concept of regional trade agreements began with Israel in 1985. Although it was fifteen years before the second FTA was signed with a Middle Eastern country (Jordan), others with Bahrain, Morocco and Oman have followed. As of 2008, negotiations continue with the United Arab Emirates (UAE). While these agreements in the aggregate likely reflect security concerns, the more recent ones have a significant economic development/support for the rule of law element as well. The U.S.-Jordan Free Trade Agreement is considered a model for the proposed US-Middle East Free Trade Agreement (US-Middle East FTA). ${ }^{25}$

\section{U.S. - Jordan Free Trade Agreement}

The FTA with Jordan (US-JO FTA), ${ }^{26}$ signed October 24, 2000, only six months after Jordan's WTO accession, ${ }^{27}$ broke significant new ground. It was not only the first U.S. FTA with an Arab country, and the first post - Uruguay Round U.S. FTA to include labor and environmental provisions in the body of the agreement, subject to the general dispute settlement provisions. The US-JO FTA is also the first U.S. FTA to deal with ecommerce issues, as well as the first and, to date, only U.S. FTA to be concluded without the benefit of the "fast-track" process for obtaining Congressional approval. ${ }^{28}$ The approval of the US-JO FTA without fast-track procedure was made possible only by the foreign policy and security considerations underlying the agreement after $9 / 11$.

\footnotetext{
${ }^{25}$ President Bush announced the U.S. intent to launch a 10-year effort to form a US-Middle East free trade area. See Mike Allen \& Karen DeYoung, Bush Calls Trade Key To Mideast; President launches Plan For U.S. Pact in Region, Wash. Post A01 (May 10, 2003).

${ }_{26}$ Agreement between the United States of America and the Hashemite Kingdom of Jordan on the Establishment of a Free Trade Area, Oct. 24, 2000, available at http://www.ustr.gov/assets/Trade Agreements/Bilateral/Jordan/asset upload file250 5112.pdf

27 April 11, 2000. WTO, Jordan and the WTO, available at http://www.wto.org/english/thewto e/countries e/jordan e.htm

$\frac{}{28}$ The fast track authority is a procedure, delegated by the U.S. Congress, gives the U.S. executive the authority to enter into trade negotiations under certain procedural requirements. See I.M DESTLER, Renewing Fast-Track Legislation 8 (Inst. Intl. Econ. 1997).
} 


\section{A. Antecedents and Rationale}

The political complexities surrounding the negotiation and U.S. implementation of the US-JO FTA were greater than with any other U.S. free trade agreement. Although there is no direct legal relationship, the existence of the US-JO FTA, as well as its timing, was linked both to the Middle East peace negotiations which taking place simultaneously, a major foreign policy initiative of the Clinton Administration, and its approval by the U.S. Congress, ${ }^{29}$ after more than a year of bickering over labor and environmental provisions, a few weeks after the September 11 attack on the World Trade Center in New York, was anything but coincidence. As reported at the time, the US-JO FTA was "intended to show U.S. appreciation of Jordan's efforts in supporting the Mideast peace process and in combating international terrorism. ... The rush to pass the Jordan trade pact illustrates how the Sept. 11 attacks have recalibrated the politics of normally divisive issues such as trade."30 The Bush Administration saw it as another means of advancing the anti-terrorism campaign. ${ }^{31}$

Jordan was, and is, a staunch ally of the U.S. Equally important from the political side, Jordan was of only two Arab countries-Egypt is the other- which has concluded a formal peace treaty with Israel. It appears to have been Clinton Administration policy, supported in the Congress, to strengthen relations with Jordan. It was thus not surprising that once the U.S. and Jordan concluded a trade and investment framework agreement in $1999,{ }^{32}$ essentially little more than an agreement to seek further agreement, the Clinton Administration moved forward quickly toward concluding a full FTA about 18 months later.

The most significant complexities were, however, not between Jordan and the U.S., but between Democrats and Republicans in the U.S. President Clinton essentially gambled that even without "fast-track" negotiating authority, limiting the ability of the Congress to amend the Agreement once negotiated or to delay its enactment once sent to the Congress for approval, and he was ultimately correct, although it is anyone's guess whether in the absence of 9/11 there would have been further lengthy delays in U.S. approval.

President Clinton and Democrats in Congress further gambled that they could include in the FTA the labor and environmental provisions that had been relegated to side agreements in NAFTA, ${ }^{33}$ and make those requirements subject to the same dispute settlement mechanism that applied to other obligations. At the time of signing in October 2000, during the heat of the presidential campaign, the US-JO FTA was hailed by the

29 United States-Jordan Free Trade Area Implementation Act, Pl. 107-43, $107^{\text {th }}$ Cong., $1^{\text {st }}$ sess., 115 Stat. 2431, 19 U.S.C. $\S 2112$ Note (2001).

30 Warren Vieth \& Janet Hook, Senate Passes Free-Trade Pact with Key Ally Jordan, Los ANGELES

TIMES, Sep. 25, 2001, at A-8.

${ }^{31} I d$.

32 Agreement between the Government of the Hashemite Kingdom of Jordan and the Government of the United States of America Concerning the development of Trade and Investment Relations, Mar. 15, 1999, U.S. - Jordan, available at http://www.jordanusfta.com/documents/tifa.pdf

33 See Chapter 5, Parts, 32 I.L.M 289 (1993). 
Clinton Administration as a "new model for trade agreements," one that could attract union support. $^{34}$ Senator Max Baucus, then chairman of the Senate Finance Committee, also saw the US-JO FTA as a precedent for future trade agreements, and did not believe that such provisions would undermine U.S. sovereignty or prevent the U.S. from enforcing its own environmental laws. ${ }^{35}$

However, President George W. Bush, like many other Republicans, was concerned "about the precedent that the labor and environmental agreements might have on future trade agreements" and seriously considered seeking changes in the negotiated text. ${ }^{36}$ Senator Phil Gramm of Texas had contended that trade agreements should not be used to deal with environmental standards and labor issues such as union rights to organize; he was quoted at the time as asserting that "From the point of view of economic policy and long-term trade policy, this was a bad agreement negotiated by another president" and asserting that the inclusion of labor and environmental provisions could lead to a loss of U.S. sovereignty. ${ }^{37}$

Even with a generally pro - trade Bush as president and a usually pro-trade Senate, there was opposition in the Senate, not because of the US-JO FTA per se, but because of fear of the Republicans that the labor and environment provisions would set a bad precedent for future U.S. FTAs. After 9/11, Bush ultimately changed his mind and supported the JFTA as concluded by the Clinton Administration. ${ }^{38}$ Also, other opponents of these provisions such as Senator Phil Gramm of Texas dropped their objections, apparently in the case of Gramm because of entreaties from Secretary of State Powell and National Security Adviser Rice. ${ }^{39}$ The Senate approved the US-JO FTA by voice vote, following earlier passage by a substantial majority of the House of Representatives. ${ }^{40}$ The National Assembly of Jordan ratified the US-JO FTA by acclamation in May $2001 .{ }^{41}$

The Bush Administration hoped to use the approval of the US-JO FTA as leverage to gain momentum for global trade talks ${ }^{42}$ and for Congressional approval of fast-track "Trade Promotion Authority," with USTR Ambassador Robert Zoellick arguing that the administration's free trade agenda (for which TPA was essential) "will send an

34 Joseph Kahn, Dual Purpose of a U.S.-Jordan Trade Pact, N.Y. TimES, Oct. 20, 2000, at A16.

${ }_{35}$ See Emily Harwood, The Jordan Free Trade Agreement: Free Trade and the Environment, 27 WM. \& MARY ENVTL. L. \& POL'Y REV. 509, 527 (2002).

36 Marc Lacey, Bush Seeking to Modify Pact on Trade with Jordan, N.Y. TIMES, Apr. 11, 2001, at A7.

37 Richard W. Stevenson, Senate Approves Bill to Lift Barriers to Trade with Jordan, N.Y. TIMES, Sep. 25,2001 , at $\mathrm{C} 1$.

${ }^{38}$ Harwood, supra note 35, at 529-530.

${ }^{39}$ Stevenson, supra note 37 , at $\mathrm{C} 1$.

${ }^{40} \mathrm{Id}$. For the benefit of non-American readers, it is noted that under Senate rules, a minority of 41 senators may block action in the Senate, since 60 votes are required to close off debate (cloture). At the time, the Democrats' Senate majority was less than 60 votes.

${ }^{41}$ The US-JO FTA was approved during the extraordinary session of the National Assembly starting April, 22, 2001. See Royal Decree, Official Gazette No. 4486, page 1664 (Apr. 1, 2001).

${ }^{42}$ Ambassador Zoellick was at the time preparing an all-out effort to launch a new round of global trade negotiations at a ministerial meeting scheduled for Doha, Qatar, in November 2001. Distribution of a draft declaration for Doha was imminent. Edward Alden \& Michael Mann, Washington Signals Push on Free Trade, FinANCIAL Times (LONDON), Sep. 25, 2001, at 13. 
unmistakable signal, with one voice, that America will lead in the promotion of free markets and free people." 43 However, TPA was not ultimately enacted until August 2002, and then by the narrowest of margins in the House. ${ }^{44}$

The fact that trade between Jordan and the U.S. was minor at the time meant that the deal had relatively little economic impact, particularly for the U.S. Jordanian exports to the U.S. could not possibly threaten U.S. industries. ${ }^{45}$ However, the economic impact of the US-JO FTA on Jordan is much more significant. Jordan is outperforming its Arabic peers in building trade and generating business with the U.S. as evidenced by the positive impact of the "qualified industrial zones" in promoting exports. ${ }^{46}$ Not only the predominant textile and apparel, but also exports to the U.S. of cosmetics, food products, jewelry, machinery and marble tops, increased substantially during the years US-JO FTA existed. ${ }^{47}$ In 2007, total Jordanian exports to the U.S. increased US \$1,328.9 billion while total U.S. exports to Jordan amount US \$856.2 million. Between 2002 and 2007, the U.S. run trade deficit with Jordan. This is due to the US-JO FTA and other trade programs.

Trade between U.S. and Jordan 2002-2007 (in millions of U.S. dollars)

\begin{tabular}{|l|r|r|r|}
\hline Year & Exports to Jordan & Imports from Jordan & \multicolumn{1}{|c|}{ Balance } \\
\hline 2002 & 404 & 412 & -8.0 \\
\hline 2003 & 492.4 & 673.5 & -181.0 \\
\hline 2004 & 551.5 & $1,093.4$ & -541.9 \\
\hline 2005 & 644.2 & $1,266.8$ & -622.7 \\
\hline 2006 & 650.3 & $1,422.1$ & -771.7 \\
\hline 2007 & 856.2 & $1,328.9$ & -472.7 \\
\hline
\end{tabular}

Source: The U.S. Census Bureau, available at $<$ http://www.census.gov/foreign-trade/balance/c5110.html $>$

\section{B. Substantive Provisions of the US-JO FTA}

The US-JO FTA is comprised of a preamble, nineteen articles, three annexes, joint statements, memorandums of understanding, and side letters. The preamble reflects not only a mix of political and economic objectives, but also Jordan's status as a developing

${ }^{43}$ Stevenson, supra note 37 , at $\mathrm{C} 1$.

${ }^{44}$ See 19 U.S.C. $\$ \S 3802$ (2002) (expired Jun. 30, 2007).

${ }^{45}$ A study conducted by the Office of Economics and the Office of Industries of the USITC, found that Jordan's exports to the U.S. would not have a measurable impact on U.S. industries, U.S. employment, and production. Based on 1999 trade figures, U.S. imports from Jordan totaled \$31 million as compared to total US imports of $\$ 1$ trillion. See U.S. International Trade Commission, Economic Impact on the United States of a U.S.-Jordan Free Trade Agreement, 5-1 Pub. No. 3340 (Sep. 2000).

46 Mohammad Nsour, Fundamental Facts of the United States-Jordan Free Trade Agreement: ECommerce, Dispute Resolution and Beyond, 27 FordHAM InT'L L.J. 742, 744-745 (2003).

${ }^{47} I d$. 
country facing special challenges. ${ }^{48}$ The US-JO FTA Preamble also makes direct reference to some newer concepts including "sustainable development", intellectual property rights, and perhaps most significantly, the promotion of higher labor standards and effective enforcement of the Parties respective environmental and labor laws.

It is irrelevant for our purpose to give a very comprehensive analysis of the history and various provisions of the US-JO FTA. Therefore, it suffices to highlight the main areas where changes in Jordan's economic and legal regime were driven by the FTA. The main provisions are set out below.

\section{Trade in Goods}

The US-JO FTA is designed to eliminate substantially all tariffs between the two parties by $2010 .^{49}$ To facilitate a smooth transition toward freer trade and minimize the economic and social costs associated with such movement, the elimination of tariffs will be fully implemented in four separate stages over a period of ten years. ${ }^{50}$ In other words, the parties adopted a tariff cut formula that divides their tariff schedules into four baskets. Tariff concessions of the US-JO FTA parties are balanced in baskets A and B. However, Jordan has more items in basket D (approximately 2384 tariff items) and the U.S. put more items in basket D (approximately 1765 tariff items). ${ }^{51}$

Although the FTA parties divided their tariff schedules into baskets, which have their own tariff implementation schedule, the parties can agree to accelerate the removal of tariffs on any range of products. ${ }^{52}$ Indeed, Jordan identified certain priority productstextiles and apparels- and expressed its desire to accelerate tariff reduction for these products. $^{53}$

The U.S. has adopted a "pay-as-you-go" budget rule to offset any loss of revenue due to the US-JO FTA. ${ }^{54}$ The U.S. Congressional Budget Office (CBO) estimated that the probable loss of revenue resulting from the FTA would be about $\$ 15$ million over a five fiscal-year window. As a result of the FTA, the U.S. suffered minimal loss of revenue. Jordan, as a developing country, depends to large extent on tariffs for revenue. Thus,

\footnotetext{
${ }^{48}$ See United States (U.S.)-Jordan: Agreement Between The United States of America and the Hashemite Kingdom of Jordan on The Establishment of a Free Trade Area, Oct. 24, 2000, 41 I. L. M. 63 (entered into force Dec. 17, 2001), preamble.

${ }^{49}$ Id. art. 2.1.

${ }^{50}$ Most tariffs are eliminated over periods of two (Basket A), four (Basket B), five (Basket C) or ten years (Basket D). Id. annex 2.1

${ }^{51}$ See United States (U.S.)-Jordan: Agreement Between The United States of America and the Hashemite Kingdom of Jordan on The Establishment of a Free Trade Area, supra note 48, annex 2.1

${ }^{52}$ The FTA allows the Joint Committee to review the results of the agreement in light of the experience. Id. art. 15.2.

${ }^{53}$ See The Joint Committee of U.S. and Jordan Discuss Acceleration of Tariff Reduction Under the FTA, Al-Rai Newspaper (Sep. 7, 2006).

${ }^{54}$ The "pay-as-you-go" rule of the Balanced Budget and Emergency Deficit Control Act of 1985 requires the government to offset any loss of revenue from reduced import tariffs through cutting on tax subsidies or by reducing mandatory/discretionary spending. See Balanced Budget and Emergency Deficit Control Act of 1985, 2 U.S.C. $\S 904$ (2000).
} 
Jordan suffered loss of revenue when it lowered or eliminated tariffs as a result of signing the FTA. ${ }^{55}$ However, Jordan offset loss of revenue resulting from lower tariffs through economic growth generated by the FTA. For example, Jordan's exports to the U.S. increased to more than US \$1.3 billion. Moreover, Jordan raised domestic taxes several times to pay for the FTA and generate the necessary revenue. ${ }^{56}$

Tariff reductions made due to the US-JO FTA did not require changes in Jordanian domestic law. The Customs Law of 1998 provides that goods entering Jordan are subject to customs duties as prescribed in the customs law. The Council of Ministers issue decisions related to tariff changes. ${ }^{57}$ Thus, there is no need to make changes in Jordan's domestic law to indicate its compliance with the FTA.

\section{Trade in Services}

Trade in services is a major trade issue for the U.S. The U.S. is a major service exporter in areas such as motion pictures, banking, and franchising. Hence, it is natural that the US-JO FTA includes a provision regarding trade in services. ${ }^{58}$ The purpose of the service provision in the US-JO FTA is to prevent discriminatory treatment between American and Jordanian suppliers of services. For example, a U.S. firm operating in Jordan will market its services under the same conditions as a Jordanian firm marketing like services.

The US-JO FTA permits trade in a wide range of services. While Jordan made new commitments that covered veterinary, audiovisual, health and education, and maritime transportation services, the U.S. did not make any new commitments. ${ }^{59}$ Rather, the U.S. incorporated its General Agreement on Trade in Services (GATS) service schedule in the FTA without modifications. ${ }^{60}$ In contrast, in the FTA, Jordan made further commitments that went beyond those it made under GATS. Therefore, Jordan's service commitments in the US-JO FTA may be considered "GATS-Plus."

The movement of natural persons is of particular importance to Jordan. However, under the US-JO FTA, the movement of natural persons is restricted. Temporary entry into the U.S. is limited to executives, managers, or specialists of a Jordanian company

\footnotetext{
${ }^{55}$ There are no statistics, made available by the Department of Statistics or Ministry of Industry and Trade, that measure accurately the amount of loss of revenue due to concluding the US-JO FTA.

${ }^{56}$ Bashar H. Malkawi, The Case of Income Tax Evasion in Jordan: Symptoms and Solutions, 15

JOURNAL OF FINANCIAL CRIME 282, 285 (2008) (there are more than 41 type of taxes imposed on Jordanians. Over the past nine years, the government modified income and sales taxes 16 times).

${ }^{57}$ See Customs Law No. 20 of 1998, art. 14.

${ }^{58}$ See United States (U.S.)-Jordan: Agreement between the United States of America and the Hashemite Kingdom of Jordan on The Establishment of a Free Trade Area, supra note 48, art. 3.

${ }^{59}$ It is impossible to analyze precisely the effects of the FTA commitments had on Jordan's marketplace and its service sector. There are no reported statistics in this regard.

${ }^{60}$ Indeed, the U.S. services schedule of the US-JO FTA makes reference to liberalization dates for certain sectors such as road transport as of 1997 knowing that the US-JO FTA was concluded in 2000. See U.S. Schedule of Specific Commitments, Apr. 15, 1994, WTO Doc. No. GATS/SC/90.
} 
that has a physical presence in the U.S. in the form of branch, subsidiary, or affiliate. ${ }^{61}$ Such entry is limited to three years with a one-time two years extension. The U.S. commitment, while covering the intra-corporate movement of senior personnel, did not extend to other categories of workers. Moreover, a Jordanian corporate employee cannot move to the U.S. unless his company already maintains a commercial presence in the U.S. The commercial presence requirement makes it difficult for Jordanian workers to enter the U.S. service market thus denying Jordan an important benefit as a result of signing the FTA.

\section{Rules of Origin}

The FTA contains preferential rules of origin. These rules are designed to guarantee that tariff concessions are enjoyed only by products of the countries that are parties to the FTA. $^{62}$ The FTA contains two types of rules of origin: a general rule that applies to all exported industrial and agricultural products, and a specific rule for textiles and apparel which are considered import-sensitive.

Under the FTA general rule of origin, in order for products to qualify for preferential treatment, the product must be "wholly" the growth, production or manufacture of Jordan. ${ }^{63}$ The concept of "wholly growth" is interpreted narrowly since all the inputs must be produced in the exporting country to qualify for preferential treatment; third party inputs are not allowed. The "wholly growth" rule of origin applies to agricultural products and primary products. A list of primary products, for example, includes mineral products, vegetable plants, and sea fishing products such as fish or shellfish.

If a product is "not wholly the growth, product, or manufacture of the party", then it must be "substantially transformed" into a "new and different article of commerce", having a new name, character, or use distinct from the article or material from which it was transformed. ${ }^{64}$ The disjunctive "or" means that one of three parts of substantial transformation test (change in name, use, or characteristic) must occur. ${ }^{65}$ The "substantial

\footnotetext{
${ }^{61}$ See U.S. Service Schedule, 4, at <http://www.ustr.gov/regions/eu-med/middleeast/ann31US.pdf>

${ }^{62}$ Paragraph 1 of article 14 of the US-JO FTA states "The parties recognize that the rules regarding eligibility for the preferential tariff treatment... are crucial to the functioning of this Agreement". See United States (U.S.)-Jordan: Agreement between the United States of America and the Hashemite Kingdom of Jordan on The Establishment of a Free Trade Area, supra note 48, art.14.1.

${ }^{63}$ Id. annex 2.2, art. 1.a. Wholly growth, product, or a manufacture of a party means a product that has been "entirely" grown, produced, or manufactured in a party and to all materials that are incorporated in the product, that have been entirely, grown, produced, or manufactured in the party's territory.

${ }^{64}$ The language of the US-JO FTA regarding rules of origin is based on U.S. law. Substantial transformation means fundamental change in form, appearance, nature or character of article which adds to value of article an amount or percentage which is significant in comparison with value which article had when exported from country in which it was first manufactured, produced or grown. See Tariff Act of 1930, 19 U.S.C.A. § 1304 (West 1930). Moreover, the U.S. Supreme Court defined substantial transformation further in Anheuser-Busch Brewing Association case. See Anheuser-Busch Brewing Assn. v. U.S., 207 U.S. 556, 561 (1908) (the court decided that manufacture implies a change, but every change is not manufacture, and yet every change in an article is the result of treatment, labor, and manipulation. There must be transformation: a new and different article must emerge, having a distinctive name, character, or use). ${ }^{65}$ Change in name only could not be in and of itself the determinative factor to meet the "substantial transformation" test. The court decided that the name factor in meeting the "substantial transformation" test
} 
transformation" test is subjective as it leaves to the custom authorities of the importing country the discretion to determine whether a certain product has undergone substantial transformation. Because of this subjectivity, it is unclear at what time and to what extent a product has to undergo a substantial transformation. For example, suppose that Jordan imports orange from Syria. Then, it manufactures or transforms the orange into orange juice in a factory in Jordan. In this case, it is clear that the orange juice is of Jordanian origin, with different name, use, or characteristics, which makes it eligible for preferential tariff treatment by the U.S. However, suppose that Jordan imports frozen concentrated orange juice from Syria. Then, it processes the frozen concentrated orange juice into liquid orange juice. In the latter case, it is not that obvious whether the liquid orange juice has undergone substantial transformation in Jordan.

Since the substantial transformation test may not suffice by itself to confer origin, the FTA also contains a mathematical requirement, known as the value-added rule or percentage rule. The value-added rule requires, in conjunction with the substantial transformation rule, that the sum of 1) the cost or value of materials produced in Jordan plus 2) the direct cost of processing operations performed in Jordan must not be less than 35 percent of the appraised value of the product at the time it enters into the U.S. ${ }^{66}$ The value-added test is designed to ensure that the process of transformation has resulted in the inclusion of a significant degree of Jordanian content. The value-added test is difficult to meet when evaluated in light of Jordan's cheap labor. For example, if a U.S. worker applies eight hours labor to an imported input, the valued-added test could be met easily because of high productivity. A Jordanian worker, on the other hand, may fail to raise the value of the product when employing the same amount of hours because of low level of productivity.

The second set of rules of origin in the US-JO FTA is specific to for textile and apparel products. These specific rules of origin for textile are protectionist and were enacted to mitigate the likely effects of textiles and apparels trading on the U.S. clothing industry. These rules were taken verbatim from U.S. regulations on rules of origin for textile products.

The old U.S. rules of origin for textiles and apparel products are found in subparagraph 9.b.iv of annex 2.2 of the US-JO FTA. ${ }^{67}$ The old U.S. rules of origin for textiles and apparels are known as the "four operations" rule." ${ }^{68}$ Under the "four

is the weakest evidence of meeting the test. See Juice Prod. Assn. V. U.S., 628 F. Supp. 978, 989 (Ct. Intl. Trade 1986).

${ }^{66}$ See United States (U.S.)-Jordan: Agreement between the United States of America and the Hashemite Kingdom of Jordan on The Establishment of a Free Trade Area, supra note 48, 1.c.

${ }^{67}$ See Textiles and Textile Products, 19 C.F.R. § 12.130.(e) (i) (2007).

${ }^{68}$ In a case of first impression, first before the U.S. CIT and then the United States Court of Appeals for the Federal Circuit in 1987 elaborated more on the U.S. textiles country of origin rules. The Court decided that "marginal operations" performed on the cotton fabric in Hong Kong did not substantially transform the fabric originated in China allowing it to enter to the U.S. duty-free. An article "usually" will not be considered to be a product of a particular country by virtue of merely having undergone dyeing and/or printing of fabrics or yarns. The court decided that there must substantial transformation: dyeing of fabric and printing when accompanied by two or more of the following finishing operations: bleaching, shrinking, 
operations"rule, a textile product will be considered a product of Jordan if the fabric is dyed and printed in Jordan and the dyeing and printing is accompanied by two or more of the following operations: bleaching, shrinking, fulling, napping, decating, permanent stiffening, weighting, permanent embossing or moireing. Under the FTA, the application of the "four operations" rule is limited to silk, cotton, man-made fiber, or vegetable fiber. Wool is excluded from the "four operations" rule, but subject to the Breaux-Cardin rule. ${ }^{69}$ Under the Breaux-Cardin rule, it is not enough for the fabric to be dyed and printed in Jordan but the constituent fibers actually must be woven in Jordan.

Rules of origin in the US-JO FTA are difficult to use and protectionist in nature. The most challenging aspect of these rules is the "substantial transformation" test, which is based on U.S. common law. ${ }^{70}$ The FTA rules of origin leave importers and exporters with uncertainty. Minimum differences in manufacturing processes or techniques will affect the treatment of products exported from Jordan. The U.S. should have adopted "tariff shift" test in the US-JO FTA. In the "tariff shift" rule, the customs authorities of the importing country can look at the tariff schedule to see if non-originating materials shifted from one heading to another as a result of the manufacturing process. The FTA rules of origin for textiles and apparels are restrictive rules designed to protect the U.S. textiles industry. For certain groups of textiles and apparel products, separate rules of origin may apply for each individual product, which makes production and exports way too complicated. These complex rules of origin offset the benefits of tariff reduction. The US-JO FTA does not include a de minimis rule that allows a percentage of nonoriginating inputs to be incorporated in the final product without undergoing substantial manufacturing process to confer origin. Additionally, the FTA does not provide an advance ruling for origin purposes, which allow exporters or importers to know the origin of their products before trading. The de minimis rule and advance origin ruling provide more certainty for exporters and importers.

The US-JO FTA states that "the Parties undertake a general obligation to strive to administer such rules of origin effectively, uniformly and consistently with the object and

fulling, napping, decating, permanent stiffening, weighting, permanent embossing, or moireing. See Mast Indus., Inc. v. U.S., 882 F. 2d. 1069 (Fed. Cir.1987).

${ }^{69}$ In order to offset the liberalization the U.S. took by agreeing to the WTO Agreement of Textiles and Clothing, it hardened the rules of origin for textile. The new U.S. rules of origin for textile products, the same as in annex 2.2 of the US-JO FTA subparagraph (a)(i), (a)(ii), or (a)(iii), under title "general rule", states that a product is considered to originate in Jordan for example if the product is 1) "wholly obtained" or "produced" in Jordan 2) the product is a yarn, thread, twine, cordage, rope or braiding, and the "constituent staple" fibers are "spun" in Jordan or the continuous filament is extruded in Jordan 3) the product is a fabric and the "constituent fibers", filaments or warns are woven, knitted, needled, tufted, felted, entangled or transformed by another fabric-making process in Jordan "or" 4) the product is any other textile or apparel product that is "wholly assembled" in Jordan from its component pieces.

${ }^{70}$ See John Simpson, Reforming Rules of Origin, J. Com. 12A (Oct. 4, 1988) (the rule of substantial transformation is too imprecise, too subjective requiring further interpretation. It is based on a case-by-case basis. The law of origin in the U.S. is highly confused). See also Paul Demaret et al., Regionalism and Multilateralism after the Uruguay Round: Convergence, Divergence and Interaction 349 (European Interu. Press 1997) (the substantial transformation rule is familiar to common-law legal system by building upon precedent, reasoning by analogy, and taking one step at a time. The rule will work in a court charged with deciding appealed cases that will create case law upon which the rule will depend. Consequently, substantial transformation is likely to be unworkable as a rule of origin for a free trade area). 
purpose of this Agreement and the WTO Agreement. ${ }^{71}$ This is at least a partial recognition that dealing with rules of origin is an extremely complex matter, particularly for developing country customs officials-such as Jordan- many of whom are poorly trained and poorly paid. The U.S. should have adopted a more enlightened, transparent, and fairer approach tailored to Jordan's specific circumstances. One method to reduce the complexity and costs of rules of origin is to liberalize these rules for certain products that are subject to very low or zero tariff rates. Whether these products are exported from Jordan or a non-FTA party is irrelevant because these products will enter the U.S. at a low tariff rate or zero tariff. The U.S. and Jordan should conduct a study of different industries and use the results as a basis to allow deviations from rules of origin of the FTA. Jordan should also create government-sponsored trade manuals that explain how traders can meet the US-JO rules of origin to penetrate the U.S. market.

\section{Electronic Commerce and the US-JO FTA}

The US-JO FTA is the first FTA to include a provision concerning electronic commerce (e-commerce). ${ }^{72}$ The e-commerce provision of the US-JO FTA applies to goods and services traded over the medium of the Internet. The FTA requires that the parties do not deviate from their existing practice of not imposing tariffs on electronic transmissions. ${ }^{73}$

The next question that must be addressed is how to identify the benefits from the ecommerce provision of the US-JO FTA. The U.S., as of 2008, has the second largest number of Internet users, estimated at 220 million, and about 70 percent of all Internet websites are based in the U.S. ${ }^{74}$ Even more, most of the world's internet revenue is generated in the U.S. and online retail sales in the U.S. are in billions of dollars. ${ }^{75}$ In

\footnotetext{
${ }^{71}$ See United States (U.S.)-Jordan: Agreement between the United States of America and the Hashemite Kingdom of Jordan on The Establishment of a Free Trade Area, supra note 48, art.14.1.

${ }^{72}$ E-commerce is understood to mean the production, distribution, marketing, sale or delivery of goods and services by electronic means. A commercial transaction can be divided into three main stages: the advertising and searching stage, the ordering and payment stage, and the delivery stage. Any or all of these stages may be carried out electronically and may therefore be covered by the concept of e-commerce. In other words, a buyer may purchase a book via the Internet and be delivered physically later on or he can purchase and download the book via the Internet. In either case, the purchase of the book could be said that it is conducted through e-commerce means. See WTO Secretariat, Development Implications of Electronic Commerce, WT/COMTD/w/51 (Nov. 23, 1998).

${ }^{73}$ See United States (U.S.)-Jordan: Agreement between The United States of America and the Hashemite Kingdom of Jordan on The Establishment of a Free Trade Area, supra note 48, art. 7.1.a.

${ }^{74}$ See Top 20 Countries with the Highest Number of Internet Users, Internet World Stats, available at $<$ http://www.internetworldstats.com/top20.htm> (last visited Sep. 20, 2008). See Loretta Chao, China Is Likely Top Internet User, Wall St. Journal B3 (March 14, 2008) (China has become the world's largest Internet user base). See also E-Commerce Takes Off, Economist 3, 20 (May 15, 2004).

${ }^{75}$ Becoming the world's largest population of Internet users is a milestone for China, but the U.S. market remains leaps and bounds ahead in terms of and e-commerce. U.S. Internet ad spending was expected to reach $\$ 21.4$ billion. Internet makes up 10\% of advertising spending in the U.S. See Chao, supra note 64. The e-commerce figures, according the U.S. Department of commerce, exclude online travel services. For example, the owner of Seattle-based expedia.com and hotels.com sold \$10 billion worth of travel (some 20 percent of travel in the U.S. is bought online). It also excludes pornography which made $\$ 2$ billion in the U.S. The figure excludes also sales of financial services, ticket-sales agencies, online dating, tracing
} 
contrast, online commerce is negligible in Jordan. As of 2008, Jordan has approximately one million Internet users. ${ }^{76}$ Most commercial websites in Jordan are aimed at cataloging and advertising products rather than selling online. ${ }^{77}$ Online commerce requires use of modern financial and credit transactions and payments via consumer credit cards. One of the obstacles for the development of e-commerce in Jordan is the fact that the number of credit card holders is small. One can describe Jordan as a cash-transaction society. ${ }^{78}$ In contrast, the U.S. is cashless society.

The differences between the U.S. and Jordan with respect to internet accessibility, efficient telecommunication infrastructure, and volume of e-commerce tip the balance in favor of the U.S. The FTA lacks legal obligations or recommendations that the two parties share information and experience regarding policies intended to encourage the development of e-commerce.

\section{Visa Obligations in the US-JO FTA and Entry of Nationals}

The FTA allows nationals of one party to enter into the territory of the other party solely to engage in substantial trade, including trade in services and technology. ${ }^{79}$ The FTA does not define the term "substantial trade." The U.S. Department of State regulations define "substantial trade" as the quantum of trade "sufficient" to ensure a "continuous flow" of trade items between the U.S. and the treaty country. ${ }^{80}$ The purpose of the FTA language is to prevent visa fraud.

The FTA also allows nationals of one party to enter into the territory of the other to establish, develop, administer, or advice on the operation of an "investment." 81 The FTA qualifies investment by requiring that a national or the company that employs that national to "have committed" or be "in the process of committing" a "substantial amount of capital or other resources to that investment. Thus, the FTA requires a significant amount of upfront investment, which may take the form of transferring money before the national of Jordan can obtain a visa. The purpose of such language is to prevent fraud. The FTA does not define "investment" or "substantial amount of capital". However, the U.S. Department of State regulations define investment to mean that an investor places of

ancestors, and gambling. The gambling business is worth $\$ 6$ billion. About $\$ 24$ billion worth of trade was done on the California-based ebay, the biggest online auctioneer. Used-car sales are now one the biggest online growth areas. The Economist, supra note 64, at 3.

${ }^{76}$ See Internet Users in Middle East, Internet World Stats, available at $<$ http://www.internetworldstats.com/middle.htm> (last visited Sep. 20, 2008).

${ }^{77}$ See Trade Facilitation and E-commerce in the ESCWA Region, U.N. Economic and Social Commission for Western Asia, at 5, U.N Doc. E/ESCWA/ED/2001/2 (2001).

${ }^{78}$ Buying through using credit card is not the norm. Cash is the norm. Generally, credit cards are accepted at major hotels, restaurants, and other establishments. There might be a lack of system of credit history check.

${ }^{79}$ See United States (U.S.)-Jordan: Agreement between The United States of America and the Hashemite Kingdom of Jordan on The Establishment of a Free Trade Area, supra note 48, art. 8.

${ }^{80}$ See Treaty Trader, Treaty Investor, or Treaty Alien in a Specialty Occupation, 22 C.F.R. $§ 41.51$ (j) (2006).

${ }^{81}$ See United States (U.S.)-Jordan: Agreement between The United States of America and the Hashemite Kingdom of Jordan on The Establishment of a Free Trade Area, supra note 48, art. 8.2. 
capital, including funds and other assets, "at risk" in a commercial sense with the objective of generating a profit. ${ }^{82}$ An investor under the FTA must play a key role in the investment whether through its establishment, development, administration, or advice in order to be eligible for an investor visa.

For the period 2002-2007, there were twenty-two trader or investor visas issued to Jordanian nationals under the visa provisions of the FTA. ${ }^{83}$ This low level of issued visas is explained by lack of interest and understanding of the visa provisions on the part of Jordanian nationals. Even if some traders or investors are interested in benefiting from the visa provisions of the US-JO FTA, there are certain thresholds that must be met before obtaining a visa. These thresholds are the commitment to engage in "substantial trade" and commit "substantial amount of capital" for investment. Not any trader or investor can meet these thresholds.

The U.S. could have incorporated a provision in the US-JO FTA that would allow entry into the U.S., for up to one year for example, of certain categories of professionals who meet minimum educational requirements, or posses designated credentials or licenses and experience, and who seek to engage in professional occupations. Categories of professionals could have included accountants, engineers, and lawyers. The incorporation of such a provision would have given Jordanian professionals an opportunity to acquire contacts and experience, which could translate into an increase of trade and investment between the U.S. and Jordan. Moreover, the U.S. could have permitted entry of Jordan's traders or investors as long as they submitted a declaration containing a good business plan, instead of the requirements of "substantial trade" or substantial amount of capital." However, immigration issues and problems with the recognition of academic and professional credentials prevented the incorporation of such a provision. The U.S. was concerned that Jordan would dump its citizens in the U.S., although placing a cap on the number of professional visas issued annually would have mitigated this concern. Additionally, U.S. trade negotiators feared a potential backlash from Congress if a provision relating to professional visas was incorporated in the FTA, as this could have been seen as setting a precedent for future FTAs especially in light of the fact that the US-JO FTA is an agreement with a low-income country. ${ }^{84}$ Jordanians are human beings and have a baccalaureate degree. They are part of the free trade operation. As the US-JO FTA currently stands and practice so far proves, the US-JO FTA is a trade

\footnotetext{
${ }^{82}$ The U.S. regulations require treaty investors to be "in possession" of and "have control" over the capital invested or being invested. Additionally, the U.S. regulations condition that capital in the process of being invested or that has been invested must be "irrevocably" committed to the enterprise. Moreover, the investment must not be passive or virtual but rather a "real" and "active" commercial or entrepreneurial undertaking, producing some service or commodity for profit and must meet applicable legal requirements for doing business in the particular jurisdiction in the U.S. Finally, the Department of State regulations require that the projected future capacity of the enterprise should generally be realizable within five years from the date the alien commences normal business activity of the enterprise.

${ }^{83}$ See Visa Statistics, U.S. Department of State, available at $<$ http://travel.state.gov/visa/frvi/statistics/statistics_1476.html $>$ (last visited Sep. 22, 2008).

${ }^{84}$ The power over immigration rests in Congress. Congress has the power to establish a uniform rule of naturalization. See U.S. Const. art. I, $\delta 8$, cl. 4. See also Lung v. Freeman, 92 U.S. 275, 280 (1875) (the passage of laws which concern the admission of citizens and subjects of foreign nations to our shores belongs to Congress. It has the power to regulate commerce with foreign nations).
} 
agreement concerned mainly with the movement of goods, but not the movement of persons.

\section{Infant Industry Protection}

The US-JO FTA has an industrial policy language aimed at protecting some industries that cannot initially offer competitive prices and quality as competing imports but nonetheless by giving them breathing room can develop over time into competitive price and quality industries. ${ }^{85}$ An infant industry is defined, in the US-JO FTA, as an industry that has recently begun to produce like or directly competitive product. Under the US-JO FTA definition, an infant industry includes an already established industry that produces a new line of product or an expansion of an already existing industry. The infant industry provision in the FTA applies to infant industries that existed prior to the conclusion of the FTA and infant industries established after the FTA came into existence.

The FTA gives preferential treatment for infant industry. It enjoys preferential treatment in safeguard procedures in situations in which imported goods may cause or threaten to cause serious injury to a domestic industry. For example, the investigative authority can give an infant industry more time to respond to a request for a public hearing, present its evidence, or provide a counter-argument against an exporter or importer. ${ }^{86}$

Obviously, the infant industry provisions are designed to protect Jordan, not the U.S., and constitute further recognition of the low state of Jordanian industrial development. ${ }^{87}$ The "infant industry" exception in article 10, to the best of the author's knowledge, appears in no other U.S. free trade agreement. The infant industry provisions provide Jordan with the authority to increase customs duties on imported goods insofar as its industrialization and development make protective measures necessary.

Based on data available from 2002-2007, twelve investigations on the application of safeguard measures were initiated upon petition from several domestic industries in

\footnotetext{
${ }^{85}$ The US-JO FTA states that "Parties recognize that, because it has recently begun to produce a like or directly competitive product described in paragraph 1 [originating good of the other party], an infant industry may face challenges that more mature industries do not encounter. As such, each Party shall ensure that the procedures described in paragraph 2 [the procedures for safeguard investigation] do not create obstacles to infant industries that seek the imposition of such measures". See United States (U.S.)Jordan: Agreement between the United States of America and the Hashemite Kingdom of Jordan on The Establishment of a Free Trade Area, supra note 48, art.10.5.

${ }^{86}$ Article 10 of the US-JO FTA establishes procedural obligations for conducting a safeguard investigation and providing notification and consultation with respect to that investigation. Id. art. 10.c.2.

${ }^{87}$ The question that arises is whether the FTA infant industry language applies also to the U.S. which is often acknowledged as having no industrial policy. See Fair Trade and Harmonization: Prerequisites for Free Trade 306-309 (Jagdish Bhagwati \& Robert E. Hudec eds., MIT Press 1996) (the United States has not had an avowed industrial policy. However, some critics have contended that the U.S. does in fact have an industrial policy in the broad sense. The U.S. has an implicit and decentralized industrial policy).
} 
Jordan. ${ }^{88}$ Of those petitions, the competent authority found serious injury in six, terminated five, and there is one outstanding investigation. None of those petitions filed were directed against the U.S. Rather, those petitions were directed at imports from China and India. Since the conclusion of the US-JO FTA, Jordan did not impose safeguard measures against U.S. imports. Products imported into Jordan from the U.S. do not form a threat to local industries. The main U.S. exports to Jordan are capital goods (vehicles, machinery, aircraft parts) and farm products (cereals). These exports cannot be produced in Jordan and they have to be imported because they are necessary for the industrial structure of Jordan. Thus, there is no competition between U.S. and Jordanian industries. The US-JO FTA did not harm domestic industries in Jordan.

\section{Intellectual Property Rights}

One of the objectives of the US-JO FTA is to emphasize the relationship between trade and intellectual property. The US-JO FTA protects copyrights, trademarks, and patents and encourages Jordan to make "its best effort" in ratifying or acceding to the Patent Cooperation Treaty of 1984 (PCT) and the 1989 Madrid agreement concerning the international registration of marks. ${ }^{89}$ As of 2008 , Jordan is not a party to the PCT and the Madrid protocol. ${ }^{90}$ There is no obvious reason why Jordan did not sign to the PCT and the Madrid protocol.

The US-JO FTA addresses how copyrighted works operate in cyberspace and are protected from Internet piracy. The US-JO FTA incorporates by reference WIPO Copyright Treaty (WCT) and WIPO Performances and Phonograms Treaty (WPPT), known as the "Internet treaties." The US-JO FTA covers anti-circumvention measures by prohibiting the circumvention of effective technological measures that protect copyright. $^{92}$ Many of these provisions reflect the increased importance of copyright protection in an increasingly digital - based economy. Under the FTA, it is illegal to disable a technology that is designed to prevent burning of the content of a $\mathrm{CD}$. The source of the FTA language is the U.S. Digital Millennium Copyright Act of 1998(DMCA), which protects intellectual property in the digital environment. ${ }^{93}$ The DMCA makes exceptions from the anti-circumvention measures language for nonprofit libraries, reverse engineering to make software interoperable, encryption research,

\footnotetext{
${ }^{88}$ Those domestic industries included biscuits and chocolates, magnetic tapes, shoes, imports of pasta, cooking appliances and plate-warmers, and unglazed ceramic flags and paving, hearth or wall tiles. See List of Accomplished Cases, Ministry of Industry and Trade, available at $<$

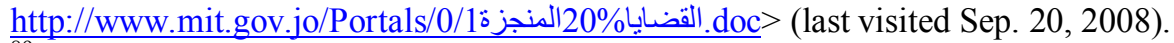

${ }^{89}$ See United States (U.S.)-Jordan: Agreement between the United States of America and the Hashemite Kingdom of Jordan on The Establishment of a Free Trade Area, supra note 48, art. 4.2.

${ }^{90}$ See PCT Contracting States, WIPO, available at $<$ http://www.wipo.int/pct/guide/en/gdvol1/annexes/annexa/ax a.pdf $>$ (last visited Sep. 24, 2008). See also Contracting Parties, WIPO, available at

$<$ http://www.wipo.int/treaties/en/ShowResults.jsp?lang=en\&treaty id=8> (last visited Sep. 24, 2008

${ }^{91}$ See United States (U.S.)-Jordan: Agreement between the United States of America and the Hashemite Kingdom of Jordan on The Establishment of a Free Trade Area, supra note 48, art. 4.10.

${ }^{92}$ Id. art. 4.13.

${ }^{93}$ See U.S. Digital Millennium Copyright Act of 1998, 17 U.S.C. $\S \S 512,1201$ (2000).
} 
protecting personal information, security testing, and preventing minor access to inappropriate materials. These exceptions are not included in the US-JO FTA.

The FTA requires Jordan to prohibit both civilly and criminally the manufacture, importation, or circulation of any technology, device, or service that is designed, produced, performed or marketed for engaging in circumventing technological measures or has only limited commercially significant purposes or uses other than enabling or facilitating such conduct. ${ }^{94}$ To comply with the anti-circumvention provisions of the USJO FTA, Jordan amended its copyright law in 2005 by providing penalties for any person who manufacture, import, or circulate of any technology, device, or service that is designed, produced, performed or marketed for circumventing technological measures. ${ }^{95}$

With respect to trademarks protection, the US-JO FTA obligates Jordan to protect well-known marks against unauthorized use. ${ }^{96}$ Prior to signing the FTA, protection of well-known trademarks in Jordan was vague and unsystematic. Due to the lack of explicit provisions preventing the registration of well-known marks, many local Jordanian companies filed applications to register these marks under their own names. The simplistic approach to register trademarks in Jordan also contributed to the registration of well-known marks. ${ }^{97}$

In the past, well-known trademarks were given protection through ad hoc or informal determinations. The Trademarks Registration Office, under Ministry of Industry and Trade, granted well-known status determination on an ad hoc basis through oppositions and cancellations. Furthermore, a court in a particular case could grant well-known status for trademarks on an ad hoc basis. The following case is an example of an ad hoc wellknown status determination granted by the Trademarks Registration Office. Farid Khalaf Company, a Jordanian company, filed to register the mark "MILLER" in Jordan for beers. Miller Brewing Company, owner of the famous mark MILLER, filed an opposition and contended that it was the owner of the famous MILLER trademark that is registered and used in several countries worldwide. Miller Brewing Company further contended that the fact that its MILLER trademark was not registered in Jordan should not adversely affect the opposition. The Jordanian Trademarks Registrar ruled in favor of Miller

\footnotetext{
${ }^{94}$ Article 4.13 of the US-JO FTA prohibits "manufacture" of a device that is designed to circumvent technological measure. This language can be called "anti-production" provision. Moreover, article 4.13 of the FTA prohibits "importation" or "circulation" of such a device. This language can be called "anticommercial activity" provision. Moreover, article 4.13 of FTA distinguishes between two cases. The first case is the prohibition against a device that is "designed", "produced", "performed", or "marketed" for engaging in such prohibited activity. In other words, the primary purpose of the device is to circumvent technological measure. The second case is where the device has "only" limited commercial significance purpose or use other than enabling or facilitating the prohibited conduct. The second case requires weighing whether the device has significant commercial purpose, other than to circumvent technological measures.

${ }^{95}$ See Copyright Law No. 52 of 2001, Official Gazette No. 4508 as amended by Law No. 9 of 2005.

${ }^{96}$ See United States (U.S.)-Jordan: Agreement between the United States of America and the Hashemite Kingdom of Jordan on The Establishment of a Free Trade Area, supra note 48, art. 4.8.

${ }^{97}$ The Jordanian law was rather lax regarding documentation. All that is required for registration of trademarks is a general or specific power of attorney. See Trademarks Law No. 33 of 1952, Official Gazette No. 1110 (June 1, 1952).
} 
Brewing Company and rejected Khalaf's Company application. ${ }^{98}$ The Registrar reasoned that Khalaf's Company registration would cause consumer deception and constitute unfair competition and false indication of origin of the goods bearing the trademark. It appears that in MILLER case deception of the consuming public was a controlling factor. In another example, Hani Al-Qudsi \& Partners, a Jordanian Company, filed a trademark application to register the mark "7ELEVEN." The Southland Corporation, a U.S. corporation, filed an opposition claiming that the Jordanian applicant was not entitled to such registration since it uses and owns the registration of the mark "7ELEVEN" in various countries worldwide. ${ }^{99}$ The Southland Corporation prevailed in its opposition not so much on merits but rather on points of procedures. The Jordanian Company did not submit its response to the opposition on time; thus the Registrar dismissed its application.

In other cases, foreign owners of well-known trademarks had to litigate in Jordan because of the trademark registrations by Jordanian persons. For example, Dar Al Dawa Development and Investment Co., a Jordanian pharmaceutical company, attempted to register the mark "Tagadar" so it can be used to distinguish certain medications.

SmithKline and French, a British-based pharmaceutical company, registered several marks using the name "Taga" alone or by attaching another syllable such as Tagamay or Tagadiane. SmithKline and French objected to the registration. After investigating the issue, the application of the Jordanian pharmaceutical company was rejected. On appeal, the High Court of Justice confirmed the decision of the Registrar by concluding that the Jordanian pharmaceutical company intended to free ride on the goodwill and fame of the British company by taking the term "Taga" and adding "dar" so that it became "Tagadar." ${ }^{100}$ The High Court of Justice stated that SmithKline and French is a famous entity. In 1982, the total sales of SmithKline and French worldwide were \$825 million and its total sales in Jordan were $£ 53000$.

In sum, well-known trademarks in Jordan had a reputation of being under protected. This impression has largely been caused by the decisions of the Registrar and judicial cases. These decisions and cases have a foreign corporation as the primary victim and a Jordanian company. Additionally, Jurisprudence in Jordan approve a local standard whereby a well-known mark would be protected if it is used and is well-known in Jordan.

Well-known marks are now expressly protected in the Jordanian Trademarks Law. The amended Trademarks Law sets out special provisions to protect well-known marks. A key issue in the well-known trademarks area is how to define the term "well-known" and what criteria to use in doing so. The amended Trademarks Law defines well-known trademarks as marks that are widely known to the relevant public in Jordan and enjoy a high international reputation. ${ }^{101}$ While the Trademarks Law defined well-known marks, this definition is fundamentally vague. The term "relevant public" used in the Trademarks

\footnotetext{
${ }^{98}$ See Miller Brewing Company v. Fareed Khalaf Company, Trademarks Registrar's Decision No. TM/35571/1142, (April 6, 1997).

${ }^{99}$ See Southland Corporation v. Hani Al-Qudsi \& Partners, Trademarks Registrar's Decision No. TM/40918/1410 (April 27, 1997).

${ }^{100}$ See High Court of Justice, Case No. 164/88, Journal of the Jordanian Bar Association, 924 (1989).

${ }^{101}$ See Trademarks Law No. 34 of 1999, article 2, Official Gazette No. 4389 as amended by Law No. 32 of 2006.
} 
Law remains unclear as to whether it refers to an urban population in a specific income class or a wider audience such as those persons involved in channels of distribution of the type of goods to which the mark applies.

The Trademarks Law entitles the proprietor to prevent all third parties from the registration of a trademark which constitutes a reproduction or translation, liable to create confusion, of a well-known mark on identical or similar goods. The Trademarks Law infused several remedies available against trademark infringers. The Trademarks Law strengthened enforcement of trademarks by raising the fine for violations to the equivalent of $\$ 4235$ instead of the $\$ 141$ fine applied in the past. ${ }^{102}$

In the enforcement record, Jordan has witnessed increase in enforcement activities. The enforcement record in Jordan should be commended. In only few years, Jordan changed its norms and standards in trademarks. Moreover, Jordan created a workable system for trademarks protection.

Raids are conducted in Jordan against traders selling chisels and screwdrivers bearing the well-known STANLEY mark owned by the U.S. company of Stanley Works. ${ }^{103}$ These raids yielded a substantial quantity of counterfeit products, and those traders' products were confiscated and later destroyed. Owners of well-known marks have a new tool to stop the importation and exportation of goods in and out of Jordan. In 2005, the Jordanian customs authority required trademark owners to provide it with copies of their respective trademarks and basic owner information. ${ }^{104}$ These procedures are designed to implement stronger customs protection by assisting the customs service in identifying counterfeit products before they enter the country. Through these procedures, well-known mark owners can move to detain suspected goods at entry and exit points.

With respect to patent protection, the US-JO FTA defines protected subject matter as well as unpatentable subject matter. A patent can be granted for any invention, whether a product or process, in all fields of technology when it meets the patentability conditions. ${ }^{105}$ Under the old Jordanian Patent Law of 1953, patent protection was only available for process patents. Patent protection for pharmaceutical and agricultural chemical products was excluded. ${ }^{106}$ The designated objective of the old law was to encourage domestic pharmaceutical companies to specialize in the production of cheap, generic versions of drugs. Process patent protects the method by which the product is

\footnotetext{
${ }^{102} I d$. article 38.1 .

${ }^{103}$ See NJQ \& Associates, "STANELY"-Police Raid on Counterfeit Products in Jordan, available at $<$ http://www.qumsieh.com/Newsletters/Newsletter_\%20August_2000/Newsletter_August_2000.html> (last visited Sep. 18, 2008).

${ }^{104}$ See NJQ \& Associates, Jordan - The Role of Customs Department in Intellectual Property Protection, available at $<$ http://www.qumsieh.com/Newsletters/ Newsletter_December_2005/

Newsletter_December_2005.html> (last visited Sep. 18, 2008).

${ }^{105}$ See United States (U.S.S.)-Jordan: Agreement between the United States of America and the Hashemite Kingdom of Jordan on The Establishment of a Free Trade Area, supra note 48, art. 4.17.

${ }^{106}$ Product patents is a process whereby the patent protects the molecular structure, thus only the developer of the product can manufacture products with the same molecular structure.
} 
produced. Therefore, if the chemical compound is made with a different process, the chemical compound concerned could be re-produced without infringing the patent.

The US-JO FTA also addresses compulsory licensing. ${ }^{107}$ The Jordanian Patents Law authorizes granting a compulsory license for the services of the government for national defense, emergency, or for public non-commercial use. ${ }^{108}$ The Patents Law stipulates another circumstance for granting a compulsory license whereby the patentee abuses his rights by preventing others from competing fairly. ${ }^{109}$ Also, the Patents Law grants compulsory licenses in cases of a failure to work or use the invention. ${ }^{110}$ The Patent Law does not define the term "work" or "use" of inventions. At any rate, the Jordanian legislator desired to protect the public interest by laying down a number of restrictions that limit the potential increase in prices or in case the protected products are not sufficiently available or available only under unacceptable conditions. Under the Patent Law of Jordan, there is no express provision dealing with compulsory licensing for drugs. However, issuing a compulsory license for drugs can fall under emergency circumstances. $^{111}$

The US-JO FTA requires Jordan to protect the exclusive rights of the data originator from misappropriation. ${ }^{112}$ In response to the US-JO FTA, Jordan prohibited generic drug applications if data submitted by a generic producer is based on data originally compiled by the brand name producer. ${ }^{113}$ Data exclusivity can delay the introduction of generic competition for existing drugs. Under the FTA, drug regulatory authorities will not allow a drug originator's registration files to be used to register a therapeutically equivalent generic variation of a medicine. ${ }^{114}$ The FTA effectively extends monopolies by drug originators and affects access to medicines. Generics will effectively be barred from entering the market, even if patent terms have expired, until the monopolies on the use of the data expire.

Jordan, according to the FTA, must protect new uses for old chemical entities for a period of three years. ${ }^{115}$ The FTA does not provide clear parameters for what would qualify as a "new use" of old chemicals. Lack of clarity for the term "new use" led to different interpretations. For example, the U.S. interprets "new use" broadly enough to include every possible new use of old chemicals such as higher dosage of an existing medicine, a new dosage form, or new use of a known product for the treatment of humans

\footnotetext{
${ }^{107}$ Id. art. 4.20 .

${ }^{108}$ See Provisional Patent Law No. 71 of 2001, Official Gazette No. 4520 (December 2, 2001), art. 22.a.

${ }^{109} I d$. art. 22.c.

${ }^{110}$ Any interested person may seek a compulsory licensing if the patentee does not work his invention for three years after the issue of the patent, or four years from the filing date of application. Id. article 22.b (1).

${ }^{111} I d$. art. 22.a.

${ }^{112}$ See United States (U.S.)-Jordan: Agreement between the United States of America and the Hashemite Kingdom of Jordan on The Establishment of a Free Trade Area, supra note 48, art. 4.22.

${ }^{113}$ See Unfair Competition and Trade Secrets Law No. 15 of 2000, Official Gazette No. 4423, art. 8 (April 2, 2000).

${ }^{114}$ Prior to 2001, domestic generic drug producers won approvals for their drugs by simply proving that the quality of their products is equivalent to the quality of brand name drugs.

${ }^{115} I d$. art. 4.22 , footnote 10 .
} 
and animals. ${ }^{116}$ On the other hand, Jordan limits the term "new use" to new molecule or substance only. So far, based on the table mentioned below regarding new uses of drugs, many U.S. pharmaceutical companies have received extended protection in Jordan for new uses of their drugs.

\section{Number of New Uses Afforded Protection}

\begin{tabular}{|c|c|c|c|c|}
\hline $\begin{array}{l}\text { Brand } \\
\text { Name }\end{array}$ & $\begin{array}{l}\text { Date of } \\
\text { Submission }\end{array}$ & $\begin{array}{l}\text { Company } \\
\text { Name }\end{array}$ & $\begin{array}{l}\text { Active } \\
\text { Ingredient }\end{array}$ & New Use \\
\hline Forlax & 2003 & Ipsen & Macrogol & $\begin{array}{l}\text { Extension of indication } \\
\text { to children from eight } \\
\text { years }\end{array}$ \\
\hline Cancidas & 2003 & MSD & Caspofungin & $\begin{array}{l}\text { Empirical therapy for } \\
\text { resumed fungal infection } \\
\text { in febrile neuropenic } \\
\text { adult patients }\end{array}$ \\
\hline Enbrel & 2004 & Wyeth & Etanercept & Ankylosing spondylitis \\
\hline Topamax & 2004 & Janssen & Topiramate & Migraine \\
\hline Gonal F & 2004 & Serono & ------ & $\begin{array}{l}\text { In females with severe } \\
\text { LH and FSH deficiency } \\
\text { in males with } \\
\text { hypogonadotrophic } \\
\text { hypogonadism }\end{array}$ \\
\hline Xyzal tab & 2005 & $\mathrm{UCB}$ & ----- & $\begin{array}{l}\text { Extension of age } \\
\text { indication twelve-six }\end{array}$ \\
\hline Humira & 2005 & Abbott & ------ & Psoriatic A \\
\hline Resperidal & 2005 & Janssen & $\begin{array}{l}------ \\
\end{array}$ & $\begin{array}{l}\text { Manic episodes } \\
\text { associated with bipolar } \\
\text { depression }\end{array}$ \\
\hline Diovan & 2005 & Novartis & ----- & $\begin{array}{ll}\begin{array}{l}\text { Post } \\
\text { infarction }\end{array} & \text { myocardial } \\
\end{array}$ \\
\hline Singulair & 2005 & MSD & ------ & $\begin{array}{l}\text { Symptomatic relief of } \\
\text { seasonal allergic rhinitis }\end{array}$ \\
\hline Novoseven & 2005 & Novonordisk & Eptacog alfa & $\begin{array}{l}\text { Glanzmann } \\
\text { thrombasthenia }\end{array}$ \\
\hline Atacandtab & 2006 & AstraZeneca & --- & Heart failure \\
\hline $\begin{array}{l}\text { Celebrex } \\
\text { cap }\end{array}$ & 2006 & Pfizer U.S. & Celecoxib & Ankylosing spondylitis \\
\hline $\begin{array}{l}\text { Remicade } \\
\text { vial }\end{array}$ & 2006 & SP & Infliximab & Plaque psoriasis \\
\hline Exlon cap & 2007 & Novartis & Rivastigmine & $\begin{array}{l}\text { Treatment of dementia } \\
\text { of Alzheimer's Disease }\end{array}$ \\
\hline Vfend tab & & Pfizer & Voriconazole & Plaque psoriasis \\
\hline
\end{tabular}

\footnotetext{
${ }^{116}$ See Richard A. Castellano, Patent Law for New Medical Uses of Known Compounds and Pfizer's Viagra Patent, 46 IDEA 283, 297 (2006).
} 


\begin{tabular}{|l|l|l|l|l|}
\hline & 2007 & & & \\
\hline Exelon cap & 2007 & Novartis & ----- & $\begin{array}{l}\text { Dementia associated } \\
\text { with } \\
\text { Disease }\end{array}$ \\
\hline $\begin{array}{l}\text { Nasonex } \\
\text { nasal spray }\end{array}$ & 2007 & $\begin{array}{l}\text { Schering } \\
\text { Plough }\end{array}$ & Mometason & Polyposis \\
\hline
\end{tabular}

Source: Industrial Property Protection Department, Ministry of Industry and Trade (Sep. 24, 2008)

Patent protection lasts twenty years from date of filing. ${ }^{117}$ The new term of patent protection under the Patent Law affects the price of pharmaceutical raw materials. Under the Old Patent Law, the use of such materials was allowed just after any process patent protection had expired. Alternatively, if a pharmaceutical company wished to use these materials during the patent protection term, royalties had to be paid to the owner of the patent. Under the new Patent Law, however, the protection period is twenty years and thus such use will not be permitted before the expiry of the term. This means, on the one hand, that payment of royalties by Jordanian companies will continue until the end of the twenty year term. On the other hand, the anticipated decrease of pharmaceutical drug prices, as a result of the expiry of the sixteen year protection, had the old Patent Law still been in force, would not occur until the end of the twenty years protection term.

The calculation of length of protection starting from date of filing means that any time spent in prosecuting the invention in the Jordanian Patent Office will be discounted from the twenty years term. After entry into effect of the US-JO FTA in 2001, the Jordanian law was modified so that the patent term can be extended for products where commercialization is delayed due to lengthy regulatory procedures. ${ }^{118}$ Extending the patent term vindicates the expectations of inventors who did not receive a twenty-year term at the time the patent was first filed. However, from the perspective of public interest and Jordanian pharmaceutical companies, the amendment of the Patent Law to extend patent term hinders the ability of these companies to produce the protected drugs soon after the expiry of the protection term. In addition, Jordanians would not be able to access cheaper medicines.

Since the year 2000, drug prices in Jordan have increased by twenty percent. ${ }^{119}$ The price increases have affected a wide range of drugs. ${ }^{120}$ Non-contagious diseases such as heart diseases, cancers, and diabetes, are major causes of death in Jordan. Drugs for these

\footnotetext{
${ }^{117}$ See Provisional Patent Law No. 71 of 2001, supra note 108, art. 17. Previously, patents were protected for a period of sixteen years. See High Court of Justice, Decision No. 114/2000, Judicial Journal 353 (2000).

${ }^{118}$ See United States (U.S.)-Jordan: Agreement between the United States of America and the Hashemite Kingdom of Jordan on The Establishment of a Free Trade Area, supra note 48, art. 4.23.a.

${ }^{119}$ See Ministry of Health, Annual Statistical Book (2006-2010), available at $<$ http://www.moh.gov.jo/reports/headermain.jsp?print parameter=yes\&lang parameter=arabic $>$ (last visited August 11, 2008).

${ }^{120} \mathrm{Id}$.
} 
diseases have become increasingly expensive. ${ }^{121}$ In the pre-2000 era, Jordan rarely suffered any shortages of drugs. However, now, more patients complain about the unavailability of certain essential drugs in hospitals. ${ }^{122}$ Also, as a result of the surge in drug price, there has been a dramatic lowering of per capita consumption of medicines Jordan. ${ }^{123}$ Patients take fewer tablets because they no longer can afford the high costs of medicine. For example, patients take one tablet a day instead of three tablets.

Several factors could contribute to increase in prices of drugs. These factors include inflation and currency values. ${ }^{124}$ Additionally, the introduction of high levels of patent protection contributes to increase in drug prices. ${ }^{125}$ Patent protection prevents generic competition for new drugs. In 2004, drugs with no generic competition comprised only three percent of the Jordanian market by value. Since then, drugs with no generic competition have captured a larger share of the domestic market and by the year 2008 these drugs comprised eleven percent. ${ }^{126}$ It is difficult to estimate how much prices of drugs may have fallen in Jordan if there were generic competition. Past studies found that generic competition causes the prices of drugs to fall. ${ }^{127}$ Thus, introducing generic competition has made prices of some drugs more affordable in Jordan.

\footnotetext{
${ }^{121}$ For instance, the prices per unit for Metformin-500 mg (anti-diabetic), Rosiglitazone maleate- $2 \mathrm{mg}$ (anti-diabetic), Simvastatin-20 mg (anti-hypertensive) are Jordanian Dinar 0.16, 0.67, and 2.25 respectively. Id.

${ }^{122}$ Patients at Jerash Public Hospital complain that Daonil drug for diabetes and Zocor drug for high cholesterol are often unavailable at the hospital's pharmacy, forcing them to resort to the private sector at their own expense, despite being covered by national health insurance. See Jawad Irshaidat, Patients Complain of Medicine Shortages in Jerash, Jordan Times 3 (February 25, 2008).

${ }^{123}$ See Ministry of Health, Annual Statistical Book (2006-2010), supra note 119.

${ }^{124}$ See Taking the Strain; Food Prices and Protest, The Economist (May 10, 2008) (As a result of inflation, there have been demonstrations and strikes in Jordan).

${ }^{125}$ The introduction of Sanofi-Aventis' Plavix in 2006 increased average unit prices for this drug from Jordanian Dinar twelve to Jordanian Dinar fifty by 2009. Increased market share for Plavix coincided with a decline in market share for a generic anti-thrombotic registered in 1999 and priced at Jordanian Dinar ten. Yet Plavix is not available in a generic form in Jordan because of the imposition of data exclusivity; Sanofi-Aventis does not have a patent for Plavix in Jordan. See Ministry of Health, Annual Statistical Book (2006-2010), supra note 119.

${ }^{126}$ See Market share of Drugs with No Generic Competition, Table 3.

${ }^{127}$ See Jayanta Bhattacharya and William B. Vogt, A Simple Model of Pharmaceutical Price Dynamics, 46 J. Law \& Econ. 599, 602 (2003). See Saami Zain, Sword or Shield? An Overview and Competitive Analysis of the Marketing of "Authorized Generics", 62 Food Drug L.J. 739, 746 (2007). See Jeremiah Helm, The Patent End Game: Evaluating Generic Entry Into A Blockbuster Pharmaceutical Market in the Absence of FDA Incentives, 14 Mich. Telecomm. Tech. L. Rev. 175, 189-193 (2007). See Ya-Chen Tina Shih, Impact of Generic Drug Entry on Cost-Effectiveness Analysis, 25.1 Medical Decision Making 71-80 (2005).
} 


\section{Market share of Drugs with No Generic Competition}

\begin{tabular}{|l|l|l|l|l|l|}
\hline 2004 & 2005 & \multicolumn{2}{|l|}{2006} & 2007 & 2008 \\
\hline Market Share (Percentage) & 3.0 & 5.3 & 7.2 & 9.1 & 11.4 \\
\hline Sales (US\$ Thousands) & 2964 & 6192 & 9217 & 13,699 & 14,296 \\
& & & & & \\
\hline
\end{tabular}

Source: Ministry of Health, Annual Statistical Book (2004-2008)

Prices of essential drugs have become beyond the reach of many Jordanians. Higher drug prices would put a strain on the public health system, and for those Jordanians without health insurance, higher prices would require significant out-of-pocket expenditure that disproportionately harms the poorest patients. ${ }^{128}$ The increase in the prices of drugs in Jordan represents one of the major threats to the health of the population, economic growth, and trade flows.

Intellectual property rights have become increasingly important. Increased international trade, global economies, and developing technologies have played a key role in the development of intellectual property laws. These factors determine the need for strong intellectual property rights regimes to attract foreign investments in local enterprises. The same factors also encourage contributions to technology transfer, creation of new jobs, and general benefit to the citizens of the host country. Several studies establish that intellectual property protection in developing countries, especially countries with low per capita incomes, directly encourage technology transfers from highly advanced technological countries through foreign direct investment. ${ }^{129}$ It has also been observed that firms are more likely to invest in countries with strong legal protections. It has been found that the smaller risk of imitation leads to a relatively larger net demand for protected products. For example, Mansfield noted that research intensive U.S. firms with easy to imitate products will not make substantial investments in countries with weak intellectual property rights protection. ${ }^{130}$

Seeing the benefits of foreign investment and the significance of intellectual property laws in encouraging these, Jordan has taken important steps to reform its legal environment for protection of intellectual property rights. Before reforming its intellectual property rights laws, however, Jordan was regarded as a weak enforcer of

\footnotetext{
${ }^{128}$ About sixty percent of Jordanians have access to health insurance. See National Health Accounts. Ministry of Health, 52 (2008), available at

$<$ http://www.moh.gov.jo/MOH/Ar/health researchdetails.php?researchid=148 $>$ (last visited August 20, 2008).

${ }^{129}$ See R. J. Shapiro and K. A. Hassett, The Economic Value of Intellectual Property (2005).

${ }^{130}$ See E. Mansfield, Intellectual Property Protection, Foreign Direct Investment and Technology Transfer, International Finance Corporation Discussion Paper No. 19 (1994).
} 
such rights, hindering the country's participation in international trade, and holding back local businesses from growth and foreign investment flow. A clear example of the weakness of intellectual property rights in Jordan before the 1990s law reform, led the United States Trade Representative Office (USTR) to put Jordan on a Special 301 Watch List. The Watch List established the general opinion that Jordan had what were considered inadequate intellectual property protection. ${ }^{131}$ Since that time, however, Jordan's success in promoting intellectual property rights has helped legitimate businesses capitalize on their intellectual property assets and operate without fear of illegal competition. ${ }^{132}$

The new intellectual property laws and amendments have laid an essential foundation for Jordan's IT sector, particularly the software sector. As a result, the IT sector in Jordan has flourished. Some twenty-five IT companies with a combined capital of Jordanian dinars (JD) 711,000 were registered at the Ministry of Industry and Trade. ${ }^{133}$ Furthermore, the number of employers was 8,000; four times as many as in 1998. According to the 2007 REACH Report, Jordan's software and ICT services industry has experienced rapid growth and become increasingly export-oriented, quickly developing the necessary capabilities to compete on a global basis. ${ }^{134}$ The protection of software in Jordan has attracted investment from Jordanians, both inside the country and those doing business abroad, as well as leading large multi-national IT firms like Intel and Microsoft to invest in Jordan's IT industry. As consequence of increase protection of the software, Jordan had attracted \$68,005,500 million in Foreign Direct Investments in its IT sector.

The pharmaceutical sector has adjusted to the new intellectual property regime. Jordan's pharmaceutical industry has always been export oriented; a fact that has not changed in light of the new intellectual property protection. The way they do business has changed dramatically, however, with a new focus on building international alliances. As a result, exports have led to recent growth in the industry. In 2004, Jordan's pharmaceutical exports amounted to $\$ 184$ million. In 2005 , this rose to $\$ 204$ million. ${ }^{135}$ These figures suggest that Jordan's pharmaceutical export base is expanding, and serves over many markets worldwide.

Additionally, the new protection of intellectual property rights in Jordan has increased pharmaceutical research and development investment. Clinical research activity has been growing at a healthy pace. For example, several PhRMA members are conducting clinical trials in Jordan. According to the International Intellectual Property

${ }^{131}$ See Prince Hassan Named Chairman of Intellectual Property Body Commission, Jordan Times (April 17, 1999).

${ }^{132}$ See Eric Garduno \& frank J. Pietrucha, Intellectual Property Rights in the Arab World, 4.1 Geo. J. Intl. Aff. 60-62 (2003).

${ }^{133}$ See Progress with IT not as Fast as Leadership, Private Sector wish, but Outlook Remains Positive, Jordan Times (December 2, 2001).

${ }^{134}$ See Information Technology Association of Jordan, REACH 4.0: Launching Jordan's Software and ICT Services Industry: An Updated Strategy and Action Plan for His Majesty King Abdullah II (2007).

${ }^{135}$ See International Intellectual Property Institute, Intellectual Property and Trade: the Case of Jordan (2005). 
Institute, Bristol-Myers Squibb initiated a three-year, 5,000-patient cardiovascular risk factor study in Jordan. ${ }^{136}$ The Pharmaceutical Manufacturers Association of America (PhRMA) established an office in Amman to serve the Middle East and North Africa region. It was PhRMA's first presence in the region. The reform undertaken by Jordan to ensure high-standard business practices was a decisive factor in the decision of the foreign investors to invest in pharmaceutical manufacturers. According to Susan Finston, PhRMA's associate vice president, 'Jordan was the place where in less than 45 business days we could open an office, get credentials, and have all of the infrastructure and the legal permits that we needed for business'. ${ }^{137}$ This climate encouraged many of the PhRMA members, including American Home Products, Astra-Zeneca, Sanofi-Aventis, Bristol-Myers Squibb, Eli Lilly, Merck Sharp and Dohme, Janssen-Cilag, GlaxoSmithKline , Novartis, Organon, Roche, Pfizer, and Schering-Plough, to establish or expand their commercial activities in Jordan. Moreover, many Jordanian pharmaceutical companies have established business links with major foreign companies, including Mundipharma, Aventis, Fujisawa, Takeda, and Chanelle. ${ }^{138}$

Moreover a recent study by Ryan shows that pharmaceutical innovator-company foreign direct investment is taking place in all links in the value-chain: Clinical R\&D went from zero to substantial; licenses to manufacture, package, and distribute have been granted to four major local companies; 78 innovative drugs entered the market after reforms with an associated nearly $\$ 4$ million in medical education. ${ }^{139}$ This study also reported medical tourism exceeded $\$ 1.3$ billion and represented a substantial proportion of all Jordanian tourism. The study also revealed that Multinational clinical R\&D introduces the newest drugs and cutting-edge medical knowledge to Jordanian doctors and health administrators.

In conclusion, reform of the intellectual property climate in Jordan has led to an increase in the number of foreign investors benefiting from such protection.. For example, over the last few years, some foreign pharmaceutical companies have become partners with Jordanian pharmaceutical companies. Many of these companies are looking to their Jordanian partners to provide marketing and distribution expertise in the Middle East market, while the Jordanian companies benefit from a broader product base and the transfer of know-how and technology. However, there are side effects for stronger intellectual property protection. For example, Jordan has witnessed increase in drug prices. On balance, review of the reform carried out by Jordan shows that stronger IPRs have influence the decisions of foreign investors who use IPRs to protect their innovations.

\footnotetext{
${ }^{136} \mathrm{Id}$

${ }^{137}$ See J. Holden, Jordan Benefits from Intellectual Property Reforms 2 (2006).

${ }^{138}$ See United Nations Industrial Development Organization, Investment Promotion Unit Jordan: Pharmaceutical Sector (2006).

${ }^{139}$ See M. P. Ryan, Pharmaceutical Foreign Direct Investment, Technology Transfer, Health Competitiveness, and the Jordan-United States Free Trade Agreement 22 (Creative and Innovative Economy Centre-Washington, DC., 2007)
} 


\section{Environment}

The environmental provisions of the US-JO FTA gives the agreement a human face because they address issues other than traditional trade matters, such as tariffs and quotas. The preamble of the FTA includes statements relating to sustainable development and the environment. ${ }^{140}$ Negotiations to incorporate non-trade related environment provisions into the FTA were undertaken to meet the demands of the U.S. administration. ${ }^{141}$ For the first time in U.S. trade history, a trade agreement included provisions that address environment in the main text of the agreement. ${ }^{142}$ The inclusion of environmental provisions in the FTA was determined more by economic and political needs that existed in the U.S. than by pressures exerted by Jordanian environmental groups.

The US-JO FTA considers lower environmental protection to be unfair trade. ${ }^{143}$ Accordingly, Jordan shall "strive" not to waive or derogate from environmental laws as an encouragement of trade with the U.S. ${ }^{144}$ However, the FTA language is non-binding because it uses mostly hortatory language. The US-JO FTA permits each country to determine its own substantive environmental laws, but requires that those laws provide high levels of environmental protection. ${ }^{145}$ The FTA neither requires harmonization of environmental laws nor sets minimum environmental standards. Therefore, the FTA does not override current Jordan or U.S. environmental laws.

Environmental laws in the US-JO FTA are defined as statutes, regulations, or provisions with the primary purpose of the protection of environment or prevention of a

\footnotetext{
${ }^{140}$ The FTA preamble states: [the U.S. and Jordan] Recognizing the objective of sustainable development, and seeking both to protect and preserve the environment and to enhance the means for doing so in a manner consistent with their respective needs and concerns at different level of economic development." See United States (U.S.)-Jordan: Agreement between the United States of America and the Hashemite Kingdom of Jordan on The Establishment of a Free Trade Area, supra note 48, preamble.

${ }^{141}$ See Richard H. Steinberg, Trade-Environment Negotiations in the E.U, NAFTA, and WTO: Regional Trajectories of Rule Development, 91 Am. J. Intl. L. 231, 232, 235 (1997) (the trade-environment agenda is driven by wealthy states with relatively stringent environmental regulations which suggests that richer countries will produce less pollution per unit of output than poorer countries).

${ }^{142}$ See Howard Mann, NAFTA and the Environment: Lessons for the Future, 13 Tul. Envt. L.J. 387, 409 (2000) (suggesting that the impact of trade agreements on sustainable development requires that the environment be treated as an issue that is "over here", inside the agreement, not "over there" in another agreement).

${ }^{143}$ See United States (U.S.)-Jordan: Agreement between the United States of America and the Hashemite Kingdom of Jordan on The Establishment of a Free Trade Area, supra note 48, art. 5.1.

${ }^{144}$ The purpose of the US-JO FTA is to prevent race to the bottom. The term "race-to-the-bottom" refers to a progressive relaxation of state environmental standards, spurred by interstate competition to attract industry that also occasions a reduction in social welfare below the levels that would exist in the absence of such competition. For more see Kirsten H. Engel, State Environmental Standard-Setting: Is There a "Race" and is it "to the Bottom," 48 Hastings L.J. 271, 297 (1997).

${ }^{145}$ The FTA states "Recognizing the right of each Party to establish its own levels of domestic environmental protection and environmental development policies, and to adopt or modify accordingly its environmental laws, each party shall strive to ensure that its laws provide for high levels of environmental protection and shall strive to continue improve those laws". See United States (U.S.)-Jordan: Agreement between the United States of America and the Hashemite Kingdom of Jordan on The Establishment of a Free Trade Area, supra note 48, art. 5.2.
} 
danger to human, animal, or plant life or health. ${ }^{146}$ These environmental laws or regulations include: those related to the prevention, abatement or control of the release, discharge, or emission of pollutants or environmental contaminants, those related to the control of environmentally hazardous or toxic chemicals, and those related to the protection of wild flora and fauna and their habitat.

Jordan shall not fail to effectively enforce its environmental laws, through a sustained or recurring course of action or inaction, in a manner affecting trade between the U.S. and Jordan. ${ }^{147}$ This language, while subject to the general dispute resolution provision in article 17 which is considered a very significant development, nevertheless has had its limitations. First, a single violation or series of violations is not sufficient to trigger dispute settlement; there must be a "sustained or recurring course of action or inaction." Secondly, the violations must affect trade between the parties. What this language ultimately means is unclear, as it is not defined in the US-JO FTA and has not been tested by litigation as of this date.

The US-JO FTA does not determine how each party will enforce its environmental laws. The FTA leaves to each party the choice of measure of enforcement. The US-JO FTA reserves to each party the right to exercise discretion in the investigation, prosecution, regulation, and compliance with environmental matters. The FTA considers a party not in violation of its obligation to "effectively enforce" its environmental laws if that party exercises reasonable discretion or makes a bona fide decision as to how allocate resources. As of 2008, no individual person or non-governmental has asserted a claim that either the U.S. or Jordan is failing to effectively enforce its environmental laws. In other words, there have been no filings of private petitions to challenge the enforcement of environmental regulations in the U.S. and Jordan.

The U.S.-JO FTA imposes trade sanctions for failure to enforce environmental protection. Trade sanctions under the US-JO FTA include tariff increases, import bans, reductions in financial aid, or other financial penalties. The FTA does not determine how to measure or quantify trade sanctions that would be commensurate with a violation of an environmental provision of the FTA. Even if the FTA attempted to provide enforceable environmental obligations, it provoked opposition in the Congress reflecting concerns that the U.S. could well be the respondent rather than the moving Party, contributing to a long delay in U.S. approval of the US-JO FTA, as noted earlier. ${ }^{148}$ To ease such concerns, the U.S. and Jordan exchange side letters, whereby both parties expressed their intention not to exercise trade sanctions for these violations. ${ }^{149}$ These letters were requested by the

146 Id. art. 5.4 .

${ }^{147}$ Id. art. 5.3 (a).

148 See Andrea N. Anderson, The United States Jordan Free Trade Agreement, United States Chile Free Trade Agreement and the United States Singapore Free Trade Agreement: Advancement of Environmental Preservation?, 29 BROOK. J. INT'L L. 1221, 1227-1230 (2004) (providing an extensive discussion of the controversy surrounding the inclusion of environmental provisions in the U.S.-Jordan free trade agreement).

${ }^{149}$ On July 23, 2001, The letters were exchanged between former USTR Robert Zoellick and Jordan's ambassador to the U.S. 
U.S., not Jordan. They were the U.S. idea. ${ }^{150}$ Although the letters exchanged between the U.S. and Jordan allay fears that trade sanctions will be invoked to enforce the environmental provisions of the FTA, the validity of these letters remains in question.

Prior to concluding the FTA with Jordan, the U.S. completed an environmental review of the agreement. ${ }^{151}$ The review focused on transboundary and global effects on trade in endangered species, migratory birds and protected areas. The review concluded that there is no evidence to show that the US-JO FTA would adversely affect Jordan's record in these areas. ${ }^{152}$ Jordan was also obligated to complete an environmental review for review by the Joint Committee of the FTA. ${ }^{153}$ However, Jordan has never submitted an environmental review. Since the US-JO FTA was concluded in 2001, there were no reports prepared and published by the U.S. or Jordan on the state of environment in their territories and how the FTA affected that state.

Overall, the US-JO FTA was a significant development in including environmental provisions in the core of the agreement for first time ever. Environmental issues are no longer viewed as secondary issues when compared with trade matters. The environmental provisions of the US-JO FTA have impacted Jordan positively. The presence of these environmental provisions helped raise awareness on the importance of protecting the environment and that trade should not come at the expense of environmental protection. In 2006, Jordan enacted an environmental law that established ministry of environment. ${ }^{154}$ The new environmental law imposes penalties on violators of its provisions. Moreover, in May 2007, an environmental police was established in Jordan to enforce environmental protection in Jordan. ${ }^{155}$ So far, there are 400 hundred personnel working in the environmental police. Although the steps adopted by Jordan thus far deserve credit, there is still work to be done. For example, Jordan needs to increase its budgetary expenditure on environmental protection. In addition, extensive publication awareness campaigns need to be launched to highlight the importance of environmental protection.

\section{Labor}

The US-JO FTA was the first trade agreement to include labor protection provisions in its main text. The agreement requires the U.S. and Jordan to "strive" to ensure that internationally recognized labor rights are recognized and protected within domestic

\footnotetext{
${ }^{150}$ See Grary G. Yerkey, USTR Says Bush Administration Supports U.S.-Jordan Free Trade Agreement "as it is," 18 Intl. Trade Rep. (BNA) 1013 (June 28, 2001) (Sen. Grassley suggested attaching "side letters" to the agreement in which the United States and Jordan promise not to use sanctions to enforce labor and environmental provisions of the accord).

${ }^{151}$ Final Environmental Review of the Agreement on the Establishment of a Free Trade Area Between the Government of the United States and the Government of the Hashemite Kingdom of Jordan, available at $<$ http://www.ustr.gov/assets/Trade Agreements/Bilateral/Jordan/asset upload file64 5111.pdf $>$.

152 Id., at 2.

${ }^{153}$ See United States (U.S.)-Jordan: Agreement between the United States of America and the Hashemite Kingdom of Jordan on The Establishment of a Free Trade Area, supra note 48, art. 15.2(f).

${ }^{154}$ See Law of Protection of Environment No. 52 of 2006, Official Gazette No. 4748 (Oct. 16, 2006).

${ }^{155}$ See Hala Khaiat, Environmental Police Starts its work in Jordan, Al-Ghad Newspaper, available at

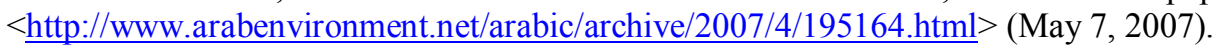


law. ${ }^{156}$ Even though the obligation is "strive" rather than "shall," this language goes beyond any prior trade agreement, and clearly reflects Clinton Administration efforts to incorporate more specific labor provisions in FTAs.

The U.S. and Jordan reaffirmed their obligations as members of the International Labor Organization (ILO). Jordan has ratified all of the ILO fundamental conventions. ${ }^{157}$ As with the environmental provisions, the FTA ensures that each party does not waive or derogate from its domestic labor laws. ${ }^{158}$ The purpose of such language is to prevent relaxation of labor laws to attract investment and increase trade. In other words, trade should not come at the expense of protecting workers' rights.

The FTA requires each party to effectively enforce its labor laws. ${ }^{159}$ The labor provisions are subject to normal dispute settlement under the US-JO FTA. Under the FTA, any non-governmental organization or individual cannot submit complaints regarding labor issues involving the other party.

The economic development, as a result of the US-JO FTA and other trade initiatives, has presented Jordan with challenges in assuring effective application of local labor laws and international standards. Some of these challenges were highlighted in a report released by the US-based NGO, National Labor Committee (NLC), in $2006 .{ }^{160}$ In light of reported labor law violations, Jordan has started enforcing its labor laws effectively. Several targeted series of inspections were undertaken covering 400 workplaces. Over 2,688 fines and 482 warnings were issued. Five factories were closed and 1,200 workers were relocated to more labor-compliant factories. ${ }^{161}$ The Ministry of Labor brought four court cases involving crimes or violations against workers between August 2006 and February 2007. Two of the cases were won by the workers and two were dismissed after the workers were compensated.

A joint industry-government code of practice, known as the Golden List, was developed to encourage enhanced employer compliance with Jordanian labor laws and

\footnotetext{
${ }^{156}$ See United States (U.S.)-Jordan: Agreement between the United States of America and the Hashemite Kingdom of Jordan on The Establishment of a Free Trade Area, supra note 48, art. 6.1.

${ }^{157}$ See Organization for Economic Cooperation and Development, International Trade and core Labor Standards 24 (2000).

${ }^{158}$ See United States (U.S.)-Jordan: Agreement between the United States of America and the Hashemite Kingdom of Jordan on The Establishment of a Free Trade Area, supra note 48, art. 6.2.

${ }^{159}$ The FTA defines labor laws as those statutes and regulations that are directly related to internationally recognized labor rights. These internationally recognized labor rights are: right of association, right to organize and bargain collectively, prohibition on the use of any form of forced or compulsory labor, minimum age for the employment of children, and acceptable conditions of work with respect to minimum wages, hours of work, and occupational safety and health. $I d$. art. 6.6.

${ }^{160}$ See Yerkey, supra note 15.

${ }^{161}$ The Ministry of Labor Closes Factors to Rectify this Working Conditions, Al-Rai Newspaper (June 5, 2006) (in Arabic).
} 
international standards. ${ }^{162}$ The Golden List code contains specific criteria pertaining to working conditions and treatment of workers. ${ }^{163}$ This code is being further revised to ensure more rigorous compliance measures.

The Jordanian government has strengthened its institutional capacity through increased allocation of resources. The Ministry of Labor significantly increased its budget for the fiscal years (FY) 2007 and 2008 to support its reform and capacity building efforts. Compared to its FY 2005 spending, the total budget for FY 2006 increased by 14 percent, and budget for FY 2007 and FY 2008 increased by approximately 40 percent.

In addition, the Jordanian government has drafted a modern version of labor law to bring the law more in line with international standards. ${ }^{164}$ Proposed changes include extension of union membership rights to guest workers, agriculture workers, and house maids. For the first time, the draft labor law refers to forced labor. The amendments to the labor law also included wage and overtime definitions. The amendments were submitted to the Prime Minister. ${ }^{165}$ The draft is currently being reviewed by the cabinet's legislative committee. Once approved by the Cabinet, the draft will be forwarded to Parliament.

The Jordanian government has embarked on a path to fully assess relevant issues, engage stakeholders in partnership, enhance labor compliance and enforcement, and strengthen long-term institutional oversight and accountability. The steps taken by the Jordanian government put itself well on its way to establish a strong labor compliance regime in full compliance with domestic and international standards. Whether the efforts taken by Jordan will be sustained depends on good faith by Jordan and the extent to which the U.S. provides Jordan with technical assistance in this area. The US-JO FTA recognizes cooperation as a mean for enhanced opportunities to improve labor standards. ${ }^{166}$ The support of the U.S. and collaboration of industry, labor, and international partners are crucial in the success of these efforts, as Jordan strives to be a model for the region on labor reform, compliance, and competitiveness.

\footnotetext{
${ }^{162}$ See Companies Listed on the Golden List, Al-Rai Newspaper (Dec. 19, 2007) (in Arabic) (The purpose of the list is to enhance corporate social responsibility in Jordan. In order for a company to be enlisted, it must obtain 80 points at least. Forty-two companies were listed on the golden list).

${ }^{163}$ The golden list addresses issues such as working hours, breaks and holidays, and work environment. Id.

${ }^{164}$ See Demands to Accelerate Enactment of Labor Law Amendments According to International Standards, Al-Rai Newspaper (May 4, 2008) (in Arabic).

${ }^{165}$ See Minister of Labor: Labor Law Amendments were Made by Different Parties, Al-Rai Newspaper (June 11, 2008) (in Arabic) (the amendments to the labor law will be forwarded to the Parliament in its next ordinary session).

${ }^{166}$ See United States (U.S.)-Jordan: Agreement between the United States of America and the Hashemite Kingdom of Jordan on The Establishment of a Free Trade Area, supra note 48, art. 6.5.
} 


\section{Other U.S.-Arab Countries FTAs}

The post - Jordan U.S. FTAs with Morocco, Bahrain and Oman represent a key element in a broader U.S. political and economic strategy to encourage economic development and democracy in the Middle East and North Africa, with most of the same political and security considerations that were material in the conclusion of the Jordan FTA. In 2003, President Bush proposed the establishment of a U.S.-Middle East Free Trade Area within a decade, so as "to re-ignite economic growth and expanded opportunity in the Middle East." $" 167$ The 9/11 Commission included a recommendation that "A comprehensive U.S. strategy to counter terrorism should include economic policies that encourage development, more open societies, and opportunities for people to improve the lives of their families and to enhance prospects for their children's future." "168 Among the elements of the Bush initiative were the completion of FTA negotiations with Morocco and the initiation of new FTA negotiations with "governments committed to high standards and comprehensive trade liberalization."169 Bahrain, Morocco, and Oman were obvious candidates, in part, because both had acceded to the WTO. ${ }^{170}$

The result to date has been the Morocco, Bahrain and Oman FTAs. ${ }^{171}$ FTA negotiations with the United Arab Emirates (UAE), a country with which the U.S. has about $\$ 5$ billion in bilateral trade, ${ }^{172}$ began in March 2005 and have not been completed. ${ }^{173}$ The three completed FTAs, while varying in minor respects from one to another, share far more similarities than differences with each other and with contemporary FTAs negotiated by the U.S.

\footnotetext{
${ }^{167}$ See White House Fact Sheet, Proposed Middle East Initiatives, May 9, 2003, at 1, available at $<\mathrm{http}$ //www.whitehouse.gov/news/releases/2003/05/print/20030509-12.html >

${ }^{168}$ See 9/11 Commission Final Report, Jul. 22, 2004, at 378-379, available at $<$ http://www.gpoaccess.gov/911/index.html >

${ }^{169} I d$. Other elements included support for WTO accession for interested Middle Eastern states and a series of trade and investment framework agreements for countries not considered ready for full FTAs.

${ }^{170}$ Bahrain and Morocco are original members of the WTO. In 2000, Oman acceded to the WTO. See WTO, Members and Observers, available at $<$ http://www.wto.org/english/thewto_e/whatis_e/tif_e/org6_e.htm> (last visited Sep. 28, 2008).

${ }^{171}$ See United States-Morocco Free Trade Agreement, available at $<$ http://www.ustr.gov/Trade_Agreements/Bilateral/Morocco_FTA/FInal_Text/Section_Index.html $>$ (June 15, 2004 ); United States-Bahrain Free Trade Agreement, available at $<$ http://www.ustr.gov/Trade_Agreements/Bilateral/Bahrain_FTA/final_texts/Section_Index.html > (Sep. 14, 2004 ); and United States-Oman FTA, available at $<$ http://www.ustr.gov/Trade_Agreements/Bilateral/Oman_FTA/Final_Text/Section_Index.html > (Jan. 19, 2006).

${ }^{172}$ See Bilaterals.org, UAE, US make progress on free trade agreement, available at $<$ http://www.bilaterals.org/article-print.php3?id_article=1950> (May 24, 2005)

173 USTR, United Arab Emirates Free Trade Agreement, available at $<$ http://www.ustr.gov/Trade_Agreements/Bilateral/UAE/Section_Index.html $>$. The expiration of U.S. Trade Promotion Authority on June 30, 2007 means that the UAE FTA, if completed, would not be subject to fast-track procedures unless TPA is renewed. However, it seems reasonably likely that if a UAE FTA resembling those with other Middle Eastern countries were concluded, Congressional approval would be forthcoming even without TPA/fast-track, as was ultimately the case with the Jordan FTA.
} 


\section{Context of the US-Morocco FTA}

Trade liberalization with Morocco will support this Administration's commitment to promote more tolerant, open, and prosperous Muslim societies. A U.S.-Morocco FTA will support the significant economic and political reforms underway in Morocco, enhance the Moroccan government's efforts to attract new trade and investment, and promote sustainable development. Such increased trade and investment can help create better jobs for Morocco's citizens. For both Morocco and the United States, implementation of the agreement of course will be critical to realizing its benefits. The Administration therefore intends to target ongoing development assistance and trade-related technical assistance to help Morocco follow through on the commitments it will make as part of the FTA. ${ }^{174}$

Morocco is also a country which has been a U.S. ally for more than 200 years; the Treaty of Peace and Friendship between the United States and Morocco, ${ }^{175}$ concluded in 1787, is said to be the oldest continuous treaty relationship of the U.S. For the Bush Administration, the conclusion of the negotiations was considered an important step toward broader Middle East reform.

As far as can easily be determined, the US-Morocco FTA was not a particularly controversial FTA in the U.S., apart from the usual non-country -- specific concerns over textiles, agriculture, intellectual property, investment, labor and environment. The US-Morocco FTA passed the House on a 323 - 99 vote, and by $85-13$ in the Senate, barely a week after President Bush sent the Agreement to Congress, truly overwhelming numbers for a free trade agreement. ${ }^{176}$

\section{Observations on the US-Morocco FTA Text}

The US-Morocco FTA consists of a preamble, 22 chapters, three general annexes with reservations to non - conforming measures; a goods schedule/annex; numerous side letters on such topics as almonds, lamb, rules of origin and government procurement and services. The US-Morocco FTA includes a chapter on sanitary and phytosanitary measures. Similarly, there is a separate chapter on technical barriers to trade. ${ }^{177}$

Textiles and apparels produced in Morocco are treated more restrictively in the U.S. market than in US-JO FTA, which permitted producers in those countries to use thirdcountry (rather than U.S. source) fabric for apparel made eligible for duty-free entry. Under the US-Morocco FTA, there is only a limited, temporary duty-free import

\footnotetext{
${ }^{174}$ See Letter from then USTR Robert Zoellick to Speaker of the House Dennis Hastert notifying intent to negotiate an FTA with Morocco, available at $<\mathrm{http}$ //www.ustr.gov/Document_Library/Letters_to_Congress/2003/Letter_to_Congress_Notifying_Intent to_Negotiate_FTA_with_Morocco.html $>(\mathrm{Jan}, \overline{2} 1, \overline{2} 003)$

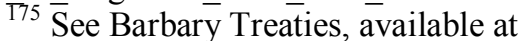
$<$ http://www.yale.edu/lawweb/avalon/diplomacy/barbary/bar1786t.htm> (Jun. 28 \& July 15, 1786)

${ }^{176}$ See Sean D. Murphy, U.S.-Morocco Free Trade Agreement, 98 AM. J. InT’L L. 835 (2004).

${ }^{177}$ See USTR, Morocco Free Trade Agreement, available at $<$ http://www.ustr.gov/Trade_Agreements/Bilateral/Morocco_FTA/FInal_Text/Section_Index.html $>$
} 
allowance for apparel made from third country fabrics. ${ }^{178}$ However, the US-Morocco FTA rules of origin for other products are somewhat different from those for textiles. The US-Morocco FTA provisions incorporate the basic 35\% local value content requirement. ${ }^{179}$ The $35 \%$ requirement may be met with unlimited quantities of materials from the U.S. The "substantially transformed" concept remains, and is explicitly defined. ${ }^{180}$ Practically speaking, the use by Moroccan producers of U.S. materials and components affect business considerations; it is obviously much more practical to ship such materials by truck from the U.S. to Mexican factories under NAFTA for example, than by ship or air 5,000 plus miles to Morocco.

Morocco accorded substantial market access across its entire services regime, subject to very few exceptions. Key services sectors covered by the US-Morocco FTA include audiovisual, express delivery, telecommunications, computer and related services, distribution, and construction and engineering. ${ }^{181}$ U.S. financial service suppliers have the right to establish subsidiaries and joint ventures in Morocco. U.S. phone companies have the right to interconnect with former monopoly networks in Morocco at nondiscriminatory, cost-based rates.

Intellectual property provisions follow the TRIPs - Plus approach, as with the US-JO FTA, reflecting to a considerable extent the changes, particularly in e-commerce and the use of the Internet, since TRIPS was negotiated in the early 1990s. The Agreement includes strong anti-circumvention provisions, requiring each government to prohibit tampering with technologies (like embedded codes on discs) that are designed to prevent piracy and unauthorized distribution over the Internet. Internet Service Providers (ISPs) have limited liability, reflecting the balance struck in the U.S. Digital Millennium Copyright act between legitimate ISP activity and the infringement of copyrights. Patent terms can be adjusted to compensate for unreasonable delays in granting the original patent, consistent with U.S. practice.

In one of the two most controversial areas of current trade negotiations (along with the environment) the US-Morocco FTA represents what many believe is a significant step away from enforceable labor rights in U.S. free trade agreements, such as the provisions of the US-JO FTA. The political controversies over these issues have been addressed under US-JO FTA, and will not be repeated here, except to note the obvious: the US-JO FTA was negotiated by the Clinton Administration, while all subsequent U.S. FTAs have been negotiated by the Bush Administration.

The US-Morocco FTA Parties reaffirm their ILO obligations, ${ }^{182}$ and the core international labor obligations found in US-JO FTA are also explicitly incorporated into

\footnotetext{
${ }^{178}$ See USTR, U.S. - Morocco Free Trade Agreement: Textile and Apparel Provisions, Jul. 19, 2004, at 1, available at $<$ http://www.ustr.gov/Document_Library/Fact_Sheets/2004/US_-

Morocco_Free_Trade_Agreement_Textile_Apparel_Provisions_printer.html $>$.

${ }_{179}$ See US-Morocco FTA, supra note 177, at art. 5.1( $\left.\bar{b}\right)$.

${ }^{180}$ Id., art. 5.14.

${ }^{181}$ See US-Morocco FTA, supra note 177.

${ }^{182} I d$., art. 16.1.
} 
the US-Morocco FTA. ${ }^{183}$ There also remains an obligation to "strive" to ensure that such international labor rights are recognized and protected by domestic law. The principal Party obligation not to "fail to enforce its labor laws, through a sustained or recurring course of action or inaction, in a manner affecting trade between the Parties, remains. ${ }^{184}$ Also included is a labor cooperation mechanism which provides some basis for bilateral cooperation on labor issues if the mechanism is adequately funded by the U.S. ${ }^{185}$ Thus, despite the change in administrations, the changes in the labor provisions are only minor. Of course, those who believe that the U.S. has consistently failed to accord labor rights a significant level of priority in trade agreements were unsatisfied with the labor provisions of US-Morocco FTA, in part because as with most developing country FTAs the FTA replaces the developing country's eligibility for the Generalized System of Preferences, which system provided somewhat greater leverage for seeking to encourage stronger enforcement of labor rights in those countries. ${ }^{186}$

The US-Morocco FTA, in large part, forced Morocco to complete difficult labor reforms, which had been stalled for some 20 years. ${ }^{187}$ A new Labor Code that entered into force on June 8, 2004 contains provisions dealing with collective bargaining, worker safety, compensation and benefits, child labor protections, gender discrimination, and layoff protections. Moreover, then Rep. Sander Levin (D-Mich.), the ranking Democrat on the Ways and Means Trade Subcommittee, was reassured by a letter from the Moroccan government that it is committed to protecting the right to strike for Moroccan workers.

In the environmental chapter, the US-Morocco FTA is similar to the US-JO FTA. Each government is required to effectively enforce its own domestic environmental laws, and this obligation is enforceable through the Agreement's dispute settlement procedures. ${ }^{188}$ Any party should not fail to effectively enforce its environmental laws, through a sustained or recurring course of action or inaction, in a manner affecting trade between the Parties.

Like the other U.S. FTA partners in the Middle East, Morocco is a small developed country, without the ability to export large quantities of any products to the U.S. According to the U.S. International Trade Commission, any increase in total U.S. textile and apparel imports from the world is likely to be very small under the US-Morocco FTA and the impact on U.S. production and employment in the textile and apparel sector is likely to be negligible. Any increase in shipments from Morocco as a result of the FTA is

\footnotetext{
${ }^{183} I d$. art. 16.7 .

${ }^{184} \mathrm{Id}$. art. 16.1(a).

${ }^{185} I d$. annex $15-\mathrm{A}$.

${ }^{186}$ See Report of the Labor Advisory Committee for Trade Negotiations and Trade Policy, The U.S.Morocco Free Trade Agreement, Apr. 6, 2004, at 4, available at

$<$ http://www.ustr.gov/assets/Trade_Agreements/Bilateral/Morocco_FTA/Reports/asset_upload file809 31 22.pdf $>$ (asserting that the MFTA provisions are weaker than those provided under GSP); 19 U.S.C. $\S \S$ 2471-2467 (2007) (setting out scope of Presidential authority to deny GSP benefits).

${ }^{187}$ See Gary G. Yerkey, Thomas Promises to Work toward House Passage of U.S.-Morocco FTA before July 25, 21 Int'1 Trade Rep. (BNA) 1211 (July 15, 2004).

188 See US-Morocco FTA, art. 17.1.
} 
likely to displace imports from other high-cost exporting countries. ${ }^{189}$ Since the conclusion of the FTA between the U.S. and Morocco, trade volume has increased between the two parties. For instance, Morocco's exports increased from US \$358 million in 2003 to US $\$ 609$ million in 2007. On the other hand, U.S. exports to Morocco increased substantially and it ran trade surplus with Morocco. In 2003, U.S. exports to Morocco stood at US \$468 million. In 2007, U.S. exports to Morocco stood at US \$1,342 billion. Among the leading U.S. exports are aircraft, corn, and machinery. Increased U.S. exports to Morocco are due to lowering tariffs which were averaging 20 percent at the time the FTA was concluded. With certain exceptions, most imported products from the U.S. into Morocco are subject to zero tariffs.

\begin{tabular}{|l|r|r|r|}
\hline Year & Exports to Morocco & Imports from Morocco & Balance \\
\hline 2005 & 525.0 & 445.8 & 79.2 \\
\hline 2006 & 878.4 & 521.4 & 357.0 \\
\hline 2007 & $1,342.7$ & 609.9 & 732.7 \\
\hline
\end{tabular}

Source: U.S. Census Bureau, available at $<$ http://www.census.gov/foreigntrade/balance/c7140.html>

The US-Morocco FTA corrected the competitive disadvantage for U.S. producers created by the association agreement concluded between Morocco and the European Union in 1995, which is intended to provide preferential tariff treatment for most EU industrial and some agricultural exports to Morocco by 2012. ${ }^{190}$ The EU currently accounts for about two-thirds of Morocco's foreign trade, with France, an EU member, being Morocco's single largest trading partner. Tariff elimination under the US-Morocco FTA gave U.S. exporters significant advantages over the EU as well as other competitor suppliers. The US-Morocco FTA leveled the playing field and increased market access for U.S. goods to Morocco. In addition, since the EU's agreement does not include agriculture, the FTA with Morocco lowers agricultural tariffs on U.S. products gave U.S. farmers an advantage. U.S. agricultural commodities that benefited from the FTA include wheat, feed grains, soybeans, and soybean products.

The FTA with the U.S. presented enormous economic opportunities for Morocco as evidenced by increased export volume over the past several years. However, agriculture trade is the toughest area in FTA, in part because almost half of Morocco's population lives in rural areas. ${ }^{191}$ In the US-Morocco FTA, Morocco agreed to eliminate tariffs on products such as pistachios, pecans, frozen potatoes, whey products, processed poultry products, pizza cheese, and breakfast cereals. The US-Morocco FTA allowed U.S. exporters to ship 700,000 tons of non-durum wheat to Morocco annually if it produces

\footnotetext{
${ }^{189}$ See USTR Fact Sheet, U.S. - Morocco Free Trade Agreement: Textile and Apparel Provisions, at 2, available at< http://www.ustr.gov/Document_Library/Fact_Sheets/2004/US_-

Morocco_Free_Trade_Agreement_Textile_Apparel_Provisions.html $>$ (July 19, 2004).

${ }^{190}$ See EU-Morocco Association Accord is Agreed to by EU Parliament, 13 Ins. Tax Rev. 24; d20 (June 12, 1996).

${ }^{191}$ Some 12 million Moroccans currently live in rural areas out of a total population of roughly 31 million.
} 
less than 2.1 million tons and 280,000 tons immediately if it produces 3 million tons a year -- eventually increasing to the European levels. The US-Morocco FTA includes a "preference clause" for all agricultural products that allows U.S. exporters to sell amounts equal to those of other countries. The FTA, moreover, established a tariff-rate quota (TRQ) for high-quality beef exports used by hotels and restaurants of 4,000 tons a year that will grow over time, with the in-quota tariff eliminated over five years and the outof-quota tariff scrapped over 18 years. Tariffs on U.S. poultry exports to Morocco are eliminated under the FTA immediately or over 5,10 , or 15 years -- depending on the poultry part, except for whole birds and leg quarters -- the two most sensitive poultry products for Morocco -- where TRQs have been initially set a 1,250 tons and 4,000 tons, respectively, and where tariffs are eliminated over 19 years and 25 years, respectively. In sum, the FTA covered four aspects of agriculture trade, including import quotas, tariff reductions, a transitional period, and an "evaluation" every year or two. The evaluation is intended to see how Morocco proceeds, how the impact is, how is the reaction of Moroccan farmers people to the agricultural portions of the agreement. The transition period could be adjusted in reaction to the evaluations.

\section{The U.S. FTAs with Bahrain and Oman}

In terms of the FTA texts themselves, the US-Bahrain and US-Oman FTAs closely resemble the US-Morocco FTA. The differences seem relatively minor. For example, the Bahrain FTA lacks an investment chapter, presumably because there is a 1999 bilateral investment treaty with the U.S. ${ }^{192}$ as does the US-JO FTA. The FTA with Oman contains the usual investment provisions and closely follows the format of the US-Morocco FTA.

The US-Bahrain FTA freed up trade in all industrial and consumer products from the day it entered into force in 2004 and also immediately brought 98 percent of Bahrain's agricultural tariffs lines to zero (alcohol and tobacco excluded). Bahrain will phase out tariffs on the remaining products within 10 years. The U.S. gave immediate duty-free access on 100 percent of Bahrain's current exports of consumer, industrial, and agricultural products to the U.S. Textiles and apparel trade are duty-free as of 2004. This promoted business opportunities for U.S. and Bahraini fiber, yarn, fabric and apparel manufacturing.

The US-Bahrain FTA strengthened intellectual property protection. Under the FTA regime, the 1993 Bahrain Copyright Law was amended to comply with the intellectual provisions of the FTA. The 1993 law included ambiguity with respect to the protection of works, performances, and sound recordings; lacked of protection on parallel imports; absence of so-called data exclusivity; and insufficient penalties for piracy. Now, the commercial pirated video and audio markets in Bahrain have been virtually eliminated. The Bahraini government made significant progress in reducing copyright piracy thus leading USTR to remove Bahrain from its Special 301 Watch List of intellectual property violators.

192 Bahrain Bilateral Investment Treaty, available at

$<\mathrm{http}$ //www.state.gov/documents/organization/43479.pdf> (Sep. 29, 1999) 
The labor provisions of the US-Bahrain FTA are fully consistent with international labor standards. These provisions were at least as strong as those contained in the US-JO FTA. Bahrain made considerable efforts to improve the labor situation. For example, Bahrain enacted a new labor law that grants workers, for the first time, freedom of association and the right to organize in trade unions and bargain collectively. Also, the new labor law grants non-Bahraini citizens the right to join labor unions. However, article 21 of the new labor law bans strikes and demonstrations at "vital establishments" throughout the country. The establishments include civil defense, airports, sea ports, hospitals, health centers and pharmacies, transportation means, and oil and gas domains. Strikes and demonstrations are prohibited at "vital establishments" where national security could be disrupted.

The impact of the US-Bahrain FTA was felt in other spheres. For example, in 2005, Bahrain agreed to dismantle its primary boycott of Israel, and that the U.S. administration will monitor and report on the issue as part of its annual National Trade Estimate Report. Bahrain has already closed its boycott office.

According to US-Oman FTA, all bilateral trade in industrial and consumer goods became duty-free immediately in 2006. Under the FTA, Oman eliminated tariffs on most U.S. imports immediately and provided substantial market access across its entire services regime. Oman provided duty-free access immediately for U.S. agricultural exports on 87 percent of all agricultural tariff lines, while the U.S. offered immediate duty-free access on 100 percent of current Omani agricultural exports to the U.S.

U.S. and Oman eliminate tariffs on textile and apparel products on the same schedule on a product-by-product basis, and that for the majority of products, tariffs are scrapped immediately or in five years. The US-Oman FTA, moreover, requires textile and apparel products to contain U.S. or Omani yarn and fabric in order to qualify for duty-free treatment. But the FTA also provides for duty-free treatment on a temporary basis for limited quantities of textile and apparel products that do not meet this requirement in order to allow U.S. and Omani producers to develop and expand business contacts. The increase in U.S. apparel imports from Oman is small in absolute value and quantity terms, and the resulting increased annual level of U.S. apparel imports from Oman are likely to remain low. Increased U.S. apparel imports from Oman are likely to displace U.S. apparel imports from other countries, rather than U.S. domestic production.

Oman has undertaken a number of significant labor law reforms since 2006, and the government is actively addressing the areas where more work needs to be done. These reforms included ratifying a number of conventions and protocols on labor of the International Labor Organization. Oman, for example, issued Royal Decree 74/2006, which ,among other things, explicitly prohibits forced labor; endorses collective bargaining and acknowledges the use of strikes as a collective bargaining technique thus removing the 1973 prohibition against strikes; provides enforcement tools for the prohibition against forced or coerced labor by providing for imprisonment and/or fines of up to $\$ 1,300$ per violation, with a doubling of the penalty for repeat offenders; terminates effective immediately Omani government involvement in union activities; prohibits 
termination of employment or any other form of employer retribution for workers performing their union duties; and increases fines fivefold for violating Oman's prohibition against the use of child labor or the improper use of female labor.

Due to concerns by members of Congress, Oman confirmed that it does not currently apply any aspect of the Arab League boycott of Israel "whether primary, secondary or tertiary or have any laws to that effect. ${ }^{193}$ Oman has no restriction whatsoever on U.S. companies trading with Oman or doing business with Oman, regardless of its ownership or relations with Israeli companies. The Omani government ensured that all ministries are aware of the situation and removed any boycott language that may unintentionally remain in their contracts.

Despite the fact that Bahrain and Oman are considerably more developed countries than either Morocco or Jordan, both the political and security considerations, as well as the economic considerations, are quite similar. Bahrain and Oman are currently relatively small markets for the U.S. Bahrain is currently the U.S. 78th largest trading partner. The two-way trade between the U.S. and Bahrain in 2007 totaled some \$1,215 billion, with the U.S. exporting about $\$ 591.3$ million worth of goods to Bahrain and Bahrain selling goods valued at some $\$ 624.6$ million to the U.S. ${ }^{194}$ Top U.S. exports to Bahrain included aircraft, machinery, arms and ammunition, and automobiles. The two-way trade in goods between the U.S. and Oman in 2007 totaled \$2,099 billion, with U.S. exports running to some $\$ 1,059.2$ billion. U.S. agricultural exports included vegetable oils, sugar, sweeteners, and beverage bases. Major non-agriculture exports to Oman included machinery, automobiles, optic and medical instruments, and electrical machinery. Imports from Oman in 2007 were $\$ 1,040.9$ billion and consisted mostly of energy and apparel products. Since both the US-Bahrain and US-Oman FTAs were concluded, trade with the U.S. has increased. The FTA with the U.S. led to increase exports from Oman and Bahrain.

\footnotetext{
193 See Gary G. Yerkey, U.S. has Commitment from Oman on Arab League Boycott of Israel, Aide Says , 23 Int'l Trade Rep. (BNA) 337 (March 6, 2006).

${ }^{194}$ See U.S. Census Bureau, Trade with Bahrain in 2007, available at $<$ http://www.census.gov/foreigntrade/balance/c5250.html\#2007> (last visited Sep. 30, 2008).
} 


\section{Conclusions}

Arab countries have been lagging behind much of the developing world in integrating into the world economy. Arab countries have taken up the challenge of using international trade as an engine of economic growth and development by engaging in trade agreements with the U.S. The US-Arab FTAs were designed both to spur Arab countries economic development and to cement strategic ties between the U.S. and these countries for geopolitical reasons.

The various FTAs between the U.S. and Arab countries, four to date, with more to come, are agreements that have been useful tools for encouraging economic development. For example, exports of Jordan increased from US \$9 million in 1998 to more than US $\$ 1.2$ billion. Thousands of jobs were created in Jordan as a result of the trade agreements between the U.S. and Jordan. Reforming intellectual property laws have laid an essential foundation for Jordan's IT sector. Jordan attracted $\$ 68,005,500$ million in Foreign Direct Investments in its IT sector. Protection of intellectual property rights in Jordan has increased pharmaceutical research and development investment. Since the conclusion of the FTA between the U.S. and Morocco, trade volume has increased between the two parties. For instance, Morocco's exports increased from US \$358 million in 2003 to US \$609 million in 2007. In addition, since the conclusion of the US-Bahrain and US-Oman FTAs, trade between these countries increased.

The conclusion of FTAs between the U.S. and other Arab countries entailed necessary internal legal and procedural reforms in most of the countries involved. These Arab countries had to reduce or eliminate substantially all tariffs on imports from the U.S. Moreover, Arab countries reformed and strengthened their laws for the protection of intellectual property rights. In Jordan, the government enacted a new environmental law that established ministry of environment and imposed penalties on violators of its provisions. Moreover, an environmental police was established in Jordan to enforce environmental protection. Jordan has started enforcing its labor laws effectively. Several targeted series of inspections have been undertaken fines and warnings have been issued. Factory closures are now more common. In addition, the Jordanian government has drafted a modern version of labor law to bring the law more in line with international standards. Proposed changes include extension of union membership rights to guest workers, agriculture workers, and house maids. For the first time, the draft labor law refers to forced labor. The US-Morocco FTA, in large part, forced Morocco to complete difficult labor reforms, which had been stalled for some 20 years. A new Labor Code that entered into force on June 8, 2004 contains provisions dealing with collective bargaining, worker safety, compensation and benefits, child labor protections, gender discrimination, and layoff protections. In Bahrain, the government enacted a new labor law that grants workers, for the first time, freedom of association and the right to organize in trade unions and bargain collectively. Also, the new labor law grants non-Bahraini citizens the right to join labor unions. Oman, for example, issued Royal Decree 74/2006, which explicitly prohibits forced labor; endorses collective bargaining and acknowledges the use of strikes as a collective bargaining technique thus removing the 1973 prohibition against strikes; provides enforcement tools for the prohibition against forced or coerced 
labor by providing for imprisonment and/or fines of up to $\$ 1,300$ per violation, with a doubling of the penalty for repeat offenders; and terminates effective immediately Omani government involvement in union activities.

Like any other agreement, these FTAs between the U.S. and Arab countries are imperfect. The FTAs with Arab countries reflect the negotiating power of the U.S. and influence of major interest groups such as intellectual property rights holders, textile producers, and agricultural interests. For example, the movement of natural persons is of particular importance to Jordan. However, under the US-JO FTA, the movement of natural persons is restricted to executives, managers, or specialists of a Jordanian company that has a physical presence in the U.S. in the form of branch, subsidiary, or affiliate. Such entry is limited to three years with a one-time two years extension. The commercial presence requirement makes it difficult for Jordanian workers to enter the U.S. service market thus denying Jordan an important benefit as a result of signing the FTA. Rules of origin in the US-JO FTA are difficult to use. The most challenging aspect of these rules is the "substantial transformation" test, which is based on U.S. common law. The FTA rules of origin leave importers and exporters with uncertainty. Textiles and apparels produced in Morocco are treated more restrictively in the U.S. market than in US-JO FTA, which permitted producers in those countries to use third-country (rather than U.S. source) fabric for apparel made eligible for duty-free entry. Under the USMorocco FTA, there is only a limited, temporary duty-free import allowance for apparel made from third country fabrics. The US-Oman FTA, moreover, requires textile and apparel products to contain U.S. or Omani yarn and fabric in order to qualify for dutyfree treatment. Agriculture trade between the U.S. and Morocco affect farmers in Morocco especially if one knows that almost half of Morocco's population lives in rural areas.

The conclusion of US-Bahrain FTA and US-Oman FTA led to poisoned relations between Bahrain and Oman on the one hand and Saudi Arabia on the other, the largest member of the Gulf Cooperation Council (GCC). ${ }^{195}$ There is a concern that the USBahrain and US-Oman FTAs function as a feeder to gain preferential market access in the customs union of the GCC. For example, U.S. exporters can use the US-Bahrain FTA to gain duty-free access to other Persian Gulf markets such as Saudi Arabia taking advantage of the common external tariff of $5 \%$ and the elimination of tariffs on intra-Gulf trade starting 2003. This ultimately breaks up the customs union among countries members of the GCC. ${ }^{196}$ To ease such concerns, the U.S. can negotiate collectively with all GCC members instead of negotiating FTAs with individual GCC members and creating a hole in the dike to get U.S. goods into Saudi Arabia for example.

\footnotetext{
${ }^{195}$ The GCC comprises Saudi Arabia, Bahrain, Kuwait, Oman, Qatar, and the United Arab Emirates.

${ }^{196}$ See Gary G. Yerkey, U.S. Will Continue to Support GCC While Negotiating Bilateral Free Trade Pacts, 22 Intl. Trade Rep. (BNA) 197 (Feb. 3, 2005) (Catherine A. Novelli, then assistant US. trade representative for Europe and the Mediterranean, stated that the U.S. will continue to support the existence of the GCC even as it negotiates FTAs with individual GCC members. The U.S. wants the GCC to succeed and has no intention in breaking in it up).
} 
In Future FTAs with other Arab countries or the US-Middle East FTA, the U.S. should "tariff shift" test whereby the customs authorities of the importing country can look at the tariff schedule to see if non-originating materials shifted from one heading to another as a result of the manufacturing process. Moreover, the US-Middle East FTA must include accumulation rule which allows Arab countries to collaborate with each other to meet the FTA's rules of origin. This leads to enhanced cooperation, rather than competition, between different producers in Arab countries. The US-Middle East FTA must include a de minimis rule that allows a percentage of non-originating inputs to be incorporated in the final product without undergoing substantial manufacturing process to confer origin. The US-Middle East FTA must provide an advance ruling for origin purposes, which allow exporters or importers to know the origin of their products before trading. The de minimis rule and advance origin ruling provide more certainty for exporters and importers. The U.S. should include a provision that allows entry into the U.S. of certain categories of professionals who meet minimum educational requirements, or posses designated credentials or licenses and experience, and who seek to engage in professional occupations.

Arab countries must adopt an export promotion scheme with the aim of increasing exports, diversifying economic activity, and attracting more foreign investment. For instance, a government entity should provide a wide range of services to manufacturers, many of whom are small and medium-size producers, with the aim of export promotion to the U.S. These services include product promotion, market information and research, technical assistance for product design and development, process improvement and export development advisory services. The governmental entity should encourage manufacturers to participate in regional and international trade fairs. U.S. embassies in Arab countries can help expand business between the parties by finding U.S. products or services, inquiring about U.S. companies, and taking business delegations to trade exhibitions in the U.S.

Free trade is insufficient in itself for economic development equation or panacea for every economic ill, without seeking improvement in rule of law, improving infrastructure, reducing unnecessary government regulation, among other things. Yet, as the paper indicated, free trade is a necessary element in the equation. The FTAs studied in this paper evidence that there are risks of free trade with the U.S. but the benefits are significant. 